\title{
TECNOSSOLOS ÚRBICOS DO PARQUE LINEAR RIBEIRÃO DAS PEDRAS, CAMPINAS/SP
}

Sara Marques PUTRINO

Francisco Sergio Bernardes LADEIRA

\begin{abstract}
RESUMO
O ponto fundamental que permite reconhecer os humanos como agentes geológicos é a possibilidade de comparação dos efeitos de suas ações aos efeitos resultantes de causas naturais, como a tectônica, mudanças climáticas, terremotos, tsunamis, etc. As profundas e, muitas vezes, abruptas intervenções humanas no meio ambiente, têm gerado, em escala crescente ao longo dos anos, sedimentos e volumes pedológicos com características muito diferentes dos naturais. Especificamente, os Tecnossolos Úrbicos (IUSS 2014) são solos profundamente modificados pela ação humana, que apresentam grande variabilidade vertical e horizontal e muitos artefatos manufaturados ao longo do perfil. A área em estudo localiza-se na região noroeste do município de Campinas/ SP, abrangendo parte da planície aluvial do ribeirão das Pedras, mais especificamente o trecho entre sua nascente e a Rodovia Dom Pedro I (SP-65). O objetivo deste trabalho foi caracterizar os Tecnossolos dessa área e compreender a história de sua formação. A metodologia adotada compreendeu a: investigação do histórico de uso e ocupação local, observação da paisagem (vegetação, ocupação), coleta de amostras de solo para a realização de análises físicas e químicas e interpretação dos resultados buscando relações entre os níveis de fertilidade, elementos contaminantes e os artefatos encontrados nos perfis. Os resultados mostraram que de maneira geral, os solos da área de estudo são arenosos, apresentam altos níveis de fertilidade e concentrações de elementos como Bário $(\mathrm{Ba})$, Cromo $(\mathrm{Cr})$, Cobre $(\mathrm{Cu})$, Chumbo $(\mathrm{Pb})$, Níquel $(\mathrm{Ni})$, Vanádio $(\mathrm{V})$ e Zinco (Zn) acima dos limites de prevenção estabelecidos pela CETESB.
\end{abstract}

Palavras-chave: Tecnossolos Úrbicos; Depósitos tecnogênicos; Solos trbanos; Artefatos antrópicos.

\section{ABSTRACT}

THE URBIC TECHNOSOLS FROM RIBEIRÃO DAS PEDRAS LINEAR PARK, CAMPINAS/SP. Humans can be considered geological agents mainly because it is possible to compare the effects of their actions with those of natural causes, such as plate tectonics, climate changes, earthquakes, tsunamis, etc. The significant and often negligent human intervention in the environment has resulted in the formation, on an increasing scale over the years, of sediments and pedological volumes with characteristics very different from those formed by natural processes. The Urbic Technosols (IUSS 2014) are soils deeply modified by humans, which show a considerable vertical and horizontal variation and many artifacts along the soil profile. The study area is located in the northwest region of the city of Campinas, SP, and covers part of the alluvial plain of the Ribeirão das Pedras river, more specifically the area between its headwater and the Dom Pedro I Highway (SP-65). The objective of this work is to characterize the Technosols and understand their formation. The methodology adopted involved: investigation of use history and local occupation, observation of the landscape (vegetation, occupation), collection of soil samples for physical and chemical analyzes, and interpretation of results to find relationships between the levels of fertility, contaminants, and artifacts found in the profile. The results showed that, in general, the soils of the study area are sandy and have high fertility levels, and that 
the concentrations of chemical elements such as Barium (Ba), Chromium (Cr), Copper $(\mathrm{Cu})$, Lead $(\mathrm{Pb})$, Nickel $(\mathrm{Ni})$, Vanadium $(\mathrm{V})$ and Zinc $(\mathrm{Zn})$ exceed the regulatory limits set by CETESB.

Keywords: Urbic Technosols; Technogenic deposits; Urban soils; Anthropic artifacts.

\section{INTRODUÇÃO}

De acordo com o último relatório elaborado pelo Departamento de Assuntos Econômicos e Sociais da Organização das Nações Unidas (UNITED NATIONS 2015) a população urbana mundial passou de 700 milhões em 1950 para aproximadamente 3,9 bilhões no ano de 2014 e as previsões indicam que as cidades abrigarão 6,3 bilhões de pessoas em 2050. No Brasil a situação se repete: dos 190.755.799 habitantes, $84,36 \%$ residem na zona urbana (IBGE - Censo Demográfico 2010).

Este processo que acaba por urbanizar antigas áreas rurais altera significativamente as características dos solos, suas funcionalidades e gênese. O termo "solos urbanos" refere-se aos solos que se encontram no meio urbano (STROGANOVA \& AGARKOVA 1993, JIM 1998, CRAUL 1999) e objetiva ressaltar um conjunto de possíveis modificações nas suas propriedades, típicas do meio urbano (PEDRON et al. 2004).

CRAUL (1985) sumarizou as modificações que os perfis de solo sofrem em áreas urbanas: grande variabilidade vertical e horizontal, intensa compactação modificando a estrutura do solo, presença de crostas superficiais que tornam a superfície impermeável à água, $\mathrm{pH}$ alterado, drenagem e aeração restritas, interrupção da ciclagem de nutrientes e modificação das atividades dos organismos do solo, presença de restos de materiais da construção civil, presença de contaminantes e modificação dos regimes de temperatura.

Complementando essas características, CURCIO et al. (2004) destacam: menor capacidade de resiliência, elevado potencial de contaminação de aquíferos, maior suscetibilidade à erosão e comportamentos geotécnicos discrepantes.

O livro Technogenic Soils of Poland (CHARZYNSKI et al. 2013) estabeleceu oito categorias de solos nas áreas urbanas. Foram analisadas características morfológicas e do uso e ocupação desses solos:

- Solos não perturbados em áreas cobertas por vegetação ou solos agrícolas nos limites da zona urbana
(Undisturbed and weakly transformed soil);

- Solos que apresentam grande quantidade de artefatos. além de variação vertical e horizontal, encontrados em áreas de construções antigas e recentes (Urbisols);

- Solos de áreas industriais e próximo a elas, onde podem ser encontrados gases, líquidos e resíduos sólidos (Industrisols);

- Solos encontrados em jardins (Garden soils);

- Solos de parques e outras áreas verdes extensas na zona urbana (Soils of parks and lawns);

- Solos de cemitérios (Necrosols);

- Solos que estão sob ruas e vias pavimentadas (Ekranosols);

-Solos desenvolvidos sobre construções antigas (Constructosols).

Do ponto de vista geológico, a intensa urbanização facilita a formação de depósitos tecnogênicos que correspondem a formações geológicas recentes, testemunhas da ação geológica humana e também do comportamento das paisagens atuais (TEIXEIRA 2015). Sua gênese está direta ou indiretamente ligada à ação da humanidade (OLIVEIRA 2005). A proposta de CHEMEKOV (1983) define os depósitos tecnogênicos como aqueles formados a partir da atividade humana, apresentando as seguintes características: diferentes processos de formação, transporte e sedimentação "tecnogênicos", composição variada, processos independentes do clima e tectônica, ampla gama de espessuras, podem ser classificados em três grupos de acordo com sua gênese, composição e morfologia, podendo ser subaéreos, subaquáticos e subterrâneos.

FANNING \& FANNING (1989) definem os depósitos tecnogênicos como depósitos altamente influenciados pelo homem e separam em quatro categorias relacionadas principalmente ao material constituinte do depósito: materiais úrbicos (restos de construção, cinzas), materiais gárbicos (lixo or- 
gânico, que em condições anaeróbias produz metano em sua decomposição), materiais espólicos (com poucos artefatos antrópicos, presentes na mineração, em áreas terraplanadas, nas estradas, nos assoreamentos induzidos por erosão acelerada) e os materiais dragados.

Para OLIVEIRA (1994) o termo caracteriza uma vasta gama de depósitos formados a partir da ação humana: induzidos pela erosão (assoreamento de canais, aluviões modernos); construídos (aterros, corpos de rejeito, resíduos de construção civil); e modificados (depósitos naturais alterados tecnologicamente: escavações, adubos, efluentes, etc.).

PELOGGIA et al. (2014), com contribuições posteriores de PELOGGIA (2015) e VITORINO et al. (2016) distinguem a diversidade de terrenos tecnogênicos em quatro classes: terrenos de agradação, degradação, modificados e complexos (PELOGGIA 2017). Os terrenos tecnogênicos são classificados de acordo com sua gênese, ou seja, baseados no seu processo de formação. Para cada uma das classes, a particularidade das camadas ou feições tecnogênicas (depósitos, solos ou formas de exposição ou mobilização dos substratos) define tipos particulares de relevos, incluindo aqueles formados por acréscimo de material (ex: planícies colmatadas, elevação de nível de base local), quanto por retirada de material (ex: terrenos erodidos) (PELOGGIA 2017).

Considerando a ação da pedogênese sobre os depósitos tecnogênicos, a edição do World Reference Base for Soil Resources (WRB) estabelece o conceito de "Tecnossolos (Technosols): solos profundamente modificados pela ação humana, cujas propriedades e pedogênese são definidas pela atividade local, estando presentes em aterros, rodovias, áreas urbanas e áreas mineradas" (IUSS 2014).

A complexidade das atividades humanas acaba por dificultar o estabelecimento de uma metodologia de identificação e classificação dos Tecnossolos. Entretanto a falta de conhecimento sobre as propriedades e aptidões desses solos tem provocado o seu mau uso. O resultado são processos de compactação, erosão, deslizamentos, inundações, poluição com substâncias orgânicas, inorgânicas e/ou patógenos, trazendo riscos e aumentando os custos de desenvolvimento da sociedade.

O objeto de estudo deste trabalho é o Parque Linear Ribeirão das Pedras, especificamente o trecho entre sua nascente e a Rodovia Dom Pedro I/SP-65, no setor noroeste do município de
Campinas, estado de São Paulo. O objetivo principal foi o de caracterizar morfologicamente e geneticamente os Tecnossolos, auxiliando na identificação de processos relacionados às dinâmicas da natureza e da sociedade.

\section{2 ÁREA DE ESTUDO}

A sub-bacia do Ribeirão das Pedras localiza-se no setor norte-noroeste do município de Campinas e está situada na Bacia Hidrográfica do Ribeirão das Anhumas, que, por sua vez, está incluída na Bacia do Rio Piracicaba através de seu afluente, o Rio Atibaia. A nascente do Ribeirão das Pedras está localizada nas coordenadas $22^{\circ} 51^{\prime} 46^{\prime \prime}$ Sul e 47 03'23" Oeste.

O baixo curso do Ribeirão das Anhumas, onde está localizada a sub-bacia do Ribeirão das Pedras, caracteriza-se por uma área em acelerado processo de urbanização. Gradualmente os bairros rurais, sítios e chácaras tem dado lugar a novos loteamentos e condomínios fechados.

O objeto de estudo deste trabalho corresponde a uma área de aproximadamente $438.000 \mathrm{~m}^{2}$, na qual está inserida a nascente e parte do alto curso do Ribeirão das Pedras (Figura 1). Essa área sofreu transformações ao longo das décadas: supressão da vegetação primária, cultivo agrícola, uso como pastagem, canalização da nascente do Ribeirão, descarte ilegal de resíduos - principalmente da construção civil, expansão urbana, e posteriormente, recuperação da vegetação ciliar.

Do ponto de vista geológico, ocorrem três litologias diferentes na área em estudo. Predominam os granitos da Suíte Granítica Jaguariúna (Proterozoico Superior) em quase toda a extensão do parque linear, duas intrusões de diabásios (Jurássico-Cretáceo) na porção nordeste e aluviões (Quaternário) às margens do Ribeirão das Pedras (FERNANDES et al. 1993).

O clima da região é classificado como subtropical de inverno seco e verão quente. Os meses de junho e julho são os mais frios, com temperatura média de $18,6^{\circ} \mathrm{C}$; agosto é o mês menos chuvoso com média de $22,9 \mathrm{~mm}$; janeiro e fevereiro são os meses mais quentes, com temperatura média de $24,8{ }^{\circ} \mathrm{C}$, e mais chuvosos, com média de 248,10 $\mathrm{mm}$ (CEPAGRI 2016).

O córrego Ribeirão das Pedras corre no sentido sul-norte por aproximadamente $9 \mathrm{~km}$ até atingir sua foz no Ribeirão das Anhumas, que deságua no Rio Atibaia, afluente do Rio Piracicaba, que desemboca posteriormente no Rio Tietê. 


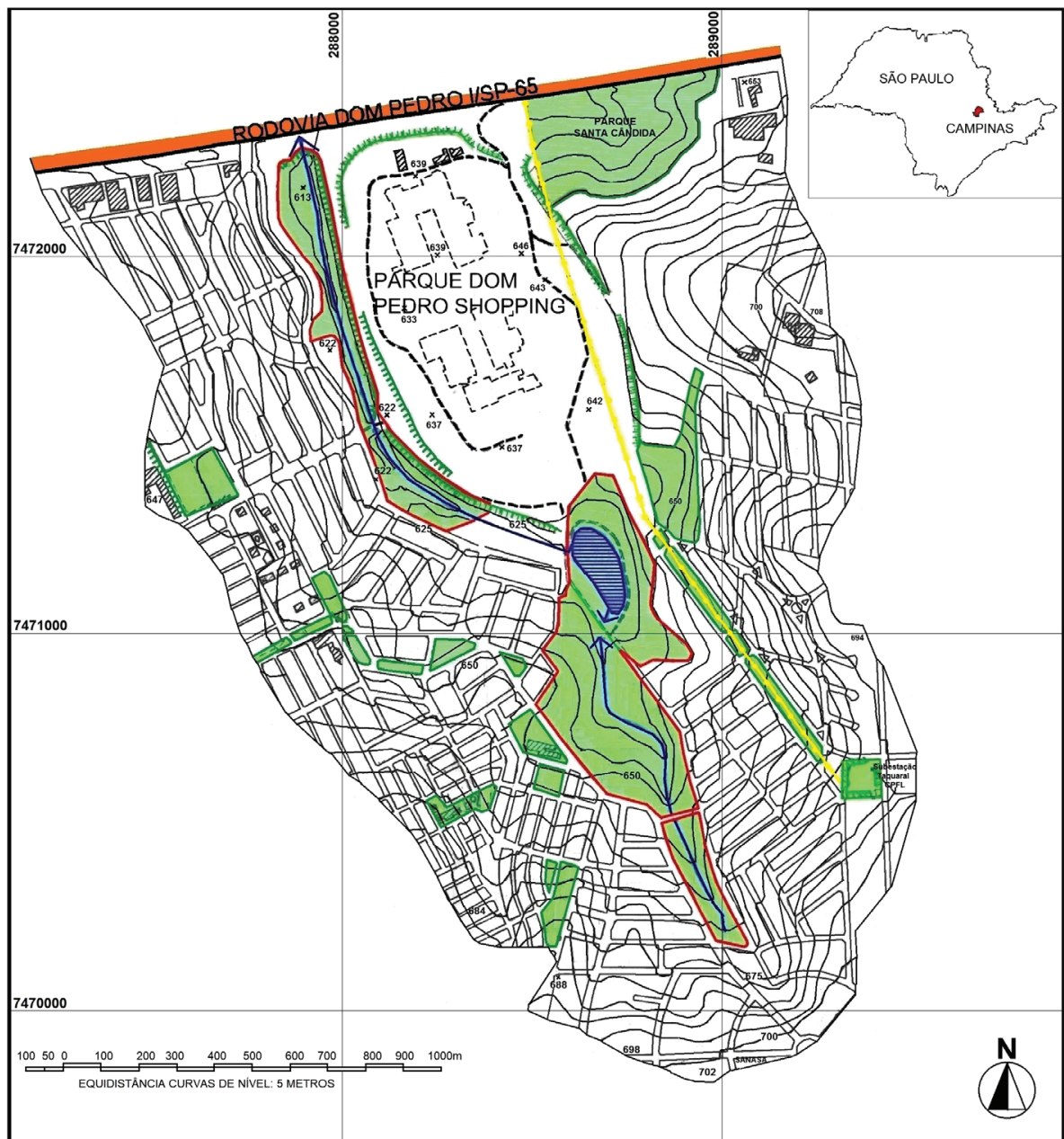

FONTE: ELABORADO A PARTIR DAS CARTAS TOPOGRÁFICAS CAMPINAS I - FOLHA SF-23-Y-A-V-4-NE-E 075/098 E CAMPINAS II FOLHA SF-23-Y-A-V-4-NE-F 075/099, ESCALA 1: 10.000 (IGC, 2002).

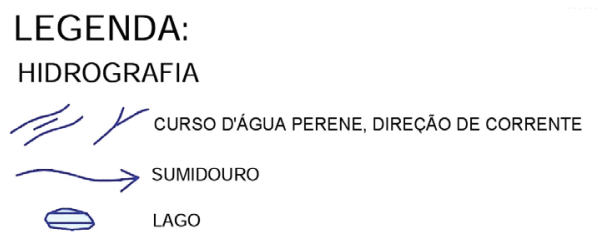

HIPSOGRAFIA E PONTOS DE REFERÊNCIA

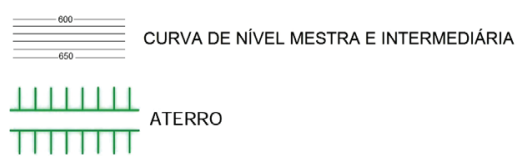

OBRAS E EDIFICAÇÕES

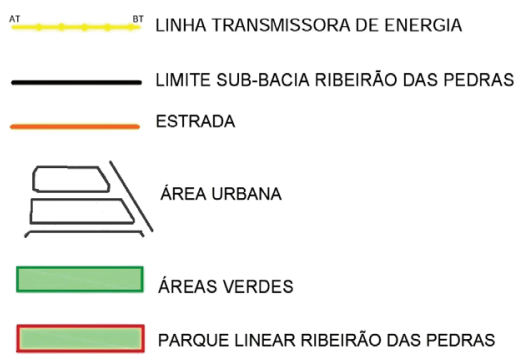

FIGURA 1 - Localização do trecho estudado da sub-bacia ribeirão das Pedras, Campinas/SP.

O Ribeirão das Pedras percorre áreas urbanizadas, condomínios residenciais, a área rural pertencente à Fazenda Santa Genebra e a área preservada correspondente a Mata Santa Genebra. A sub-bacia do Ribeirão das Pedras está quase que inteiramente inserida no município de Campinas, apenas uma pequena porção está no município de Paulínia (DAGNINO 2007).
O município de Campinas localiza-se na transição de dois compartimentos morfológicos: o Planalto Atlântico, a leste, e a Depressão Periférica, a oeste.

Segundo CHRISTOFOLLETI \& FREDERICI (1972) o Planalto Atlântico é uma grande unidade de relevo elaborada sobre rochas ígneas (granitos) e metamórficas (gnaisses e xis- 
tos). O planalto é composto por relevo escarpado, com desníveis de 800 a 1.000 m (na Serra do Mar), até formas amorreadas, de inclinação moderada e arredondadas pela ação do intemperismo, com desníveis de 100-200 m. A Depressão Periférica Paulista foi elaborada predominantemente sobre terrenos sedimentares de idades Paleozoica e Mesozoica com cotas mais baixas que o Planalto Atlântico. "Seu relevo é pouco movimentado, colinoso, de vertentes suaves, com altitudes oscilando entre 550 e 700 metros e declives que não fazem ângulo de mais de 10 graus" (CHRISTOFOLETTI \& FREDERICI, 1972, p. 25). A sub-bacia hidrográfica do Ribeirão das Pedras encontra-se na área de transição entre o Planalto Atlântico e a Depressão Periférica Paulista. De acordo com CAMPINAS (2013) o relevo da área pode ser classificado como "colinoso suavemente ondulado".

De acordo com COELHO et al. (2008) ocorrem naturalmente na área de estudo (alto curso da sub-bacia do Ribeirão das Pedras), as seguintes classes de solo (Figura 2):

- CXbe1: Cambissolo Háplico Eutrófico típico, A moderado, textura argilosa e cascalhenta; ocorre na porção nordeste do trecho estudado da sub-bacia;

- LVAd5: Latossolo Vermelho - Amarelo Distrófico típico, A moderado, textura argilosa; ocorre em uma pequena faixa na porção noroeste da sub-bacia;

- LVe1: Latossolo Vermelho Eutrófico típico, A moderado, textura argilosa; ocorre no trecho entre a lagoa do Jardim Santa Genebra até a Rodovia Dom Pedro I/SP-65;

- PAe1: Argissolo Amarelo Eutrófico típico, A moderado, textura arenosa média; ocorre no trecho entre a nascente do Ribeirão até a lagoa do Jardim Santa Genebra.

Diretamente relacionada ao solo, a vegetação é um indicador ambiental fundamental para o diagnóstico, manejo e recuperação de ecossistemas. Suas relações com o meio interferem na estabilização do terreno, quantidade e qualidade da água, ciclagem de nutrientes, manutenção do microclima local, abrigo para a fauna, entre outros (GOMES 2006). A vegetação do município de Campinas é classificada como Floresta Ombrófila Densa (IBGE 2012).

Sabendo da importância das relações solo-vegetação considerou-se a realização do levantamento das condições de arborização do Parque Linear Ribeirão das Pedras. A vegetação da área de estudo foi classificada como secundária em estágio inicial de regeneração (SMA/SP-IBAMA 1994).

O Parque Linear Ribeirão das Pedras é um projeto desenvolvido pela Prefeitura de Campinas em parceria com universidades, sociedade civil, iniciativa privada e Ministério Público. Parte do projeto foi concluído em 1999, outro trecho em 2002, e possibilitou a recuperação das matas ciliares e a formação de um parque linear com $10 \mathrm{~km}$ de extensão, atravessando 23 bairros. O Parque Dom Pedro Shopping, inaugurado em 19 de março de 2002, impactou diretamente no setor estudado da sub-bacia Ribeirão das Pedras e, de acordo com seu sistema de gestão ambiental, o empreendimento plantou 25 mil mudas nativas na área do Parque Linear; conta ainda com uma estação de tratamento de efluentes com capacidade para tratar até $2.000 \mathrm{~m}^{3} /$ dia, o que possibilita a reutilização de dois terços do volume diário de água. O restante é lançado no Ribeirão das Pedras com mais de $95 \%$ de eficiências de tratamento (FGV/ EASP 2004).

A instalação do Parque Linear Ribeirão das Pedras deveria proporcionar ganhos socioambientais para a região, tais como reflorestamento, conforto térmico, atração da fauna e uma nova opção de lazer e práticas esportivas. Entretanto o que se viu durante os trabalhos de campo foi uma área abandonada, sem qualquer manutenção nos equipamentos de lazer (pista de caminhada/corrida e ciclovia), sem contenção dos processos erosivos, sem manejo da vegetação com o crescimento de trepadeiras e espécies exóticas, descarte irregular de lixo e entulho e poucos frequentadores.

\section{MATERIAIS E MÉTODOS}

Os dados obtidos com a revisão bibliográfica, análise da paisagem, trabalhos de campo e análise das amostras coletadas foram relacionados à caracterização e a qualidade ambiental dos solos encontrados

A partir de campos de reconhecimento foi estabelecido o trecho entre a nascente e a Rodovia Dom Pedro I (SP-65) do Parque Linear Ribeirão das Pedras como área de estudo. Em seguida realizou-se um trabalho de campo para definição dos pontos de interesse para a abertura de nove trincheiras e coleta de amostras de solo para análise. A metodologia adotada foi o caminhamento por toda a extensão do Parque Linear Ribeirão das Pedras, identificando processos naturais e antró- 


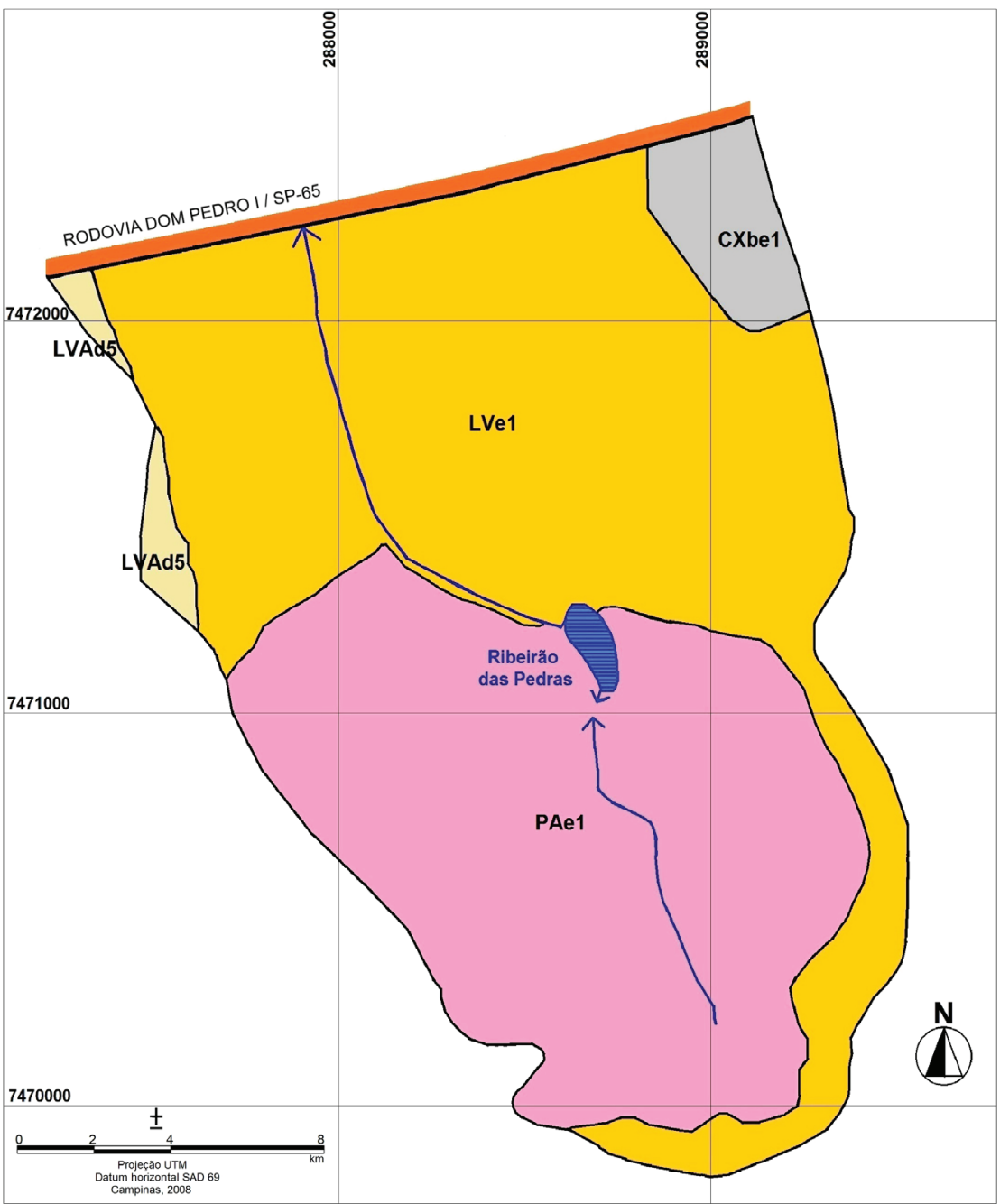

FONTE: ELABORADO A PARTIR DO MAPA PEDOLÓGICO SEMIDETALHADO DO MUNICIPIO DE CAMPINAS, SP, ESCALA 1:50.000 (COELHO et. al. 2008).

\section{LEGENDA:}

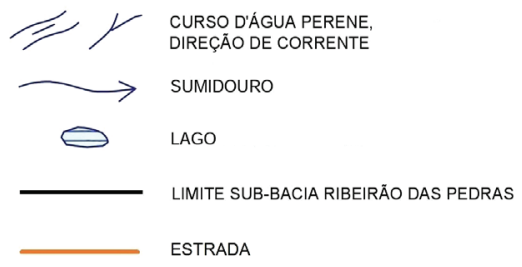

UNIDADES PEDOLÓGICAS

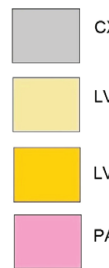

CXbe1 - CAMBISSOLO HÁPLICO Tb EUTRÓFICO TIPICO, A MODERADO TEXTURA ARGILOSA CASCALHENTA

LVAd5 - LATOSSOLO VERMELHO-AMARELO DISTRÓFICO TÍPICO, A MODERADO, TEXTURA ARGILOSA

LVE1 - LATOSSOLO VERMELHO EUTRÓFICO TÍPICO, A MODERADO, TEXTURA ARGILOSA

PAd1 - ARGISSOLO AMARELO DISTRÓFICO TIPICO, A MODERADO, TEXTURA MÉDIA/ARGILOSA

FIGURA 2 - Mapa de solos naturais do trecho estudado da sub-bacia ribeirão das Pedras, Campinas/SP.

picos. Todos os pontos estudados estão localizados na margem direita do Ribeirão das Pedras, sendo alguns aspectos considerados para essa escolha, como o uso e ocupação na margem esquerda do Ribeirão (residências, centro de saúde, campo de futebol, cultivo de hortaliças), que impediriam a coleta de amostras de solo, e a facilidade de acesso.
Para melhor entendimento a área em estudo foi dividida em três setores: Setor A, Setor B e Setor C (Figura 3). No Setor A, próximo a nascente do Ribeirão das Pedras, o uso e ocupação do entorno é predominantemente residencial. Nos Setores B e C foram identificados diferentes usos do solo: comercial, residencial, cultivo de hortaliças, Esporte Clube Alvorecer, base da Polícia Militar, entre outros. 


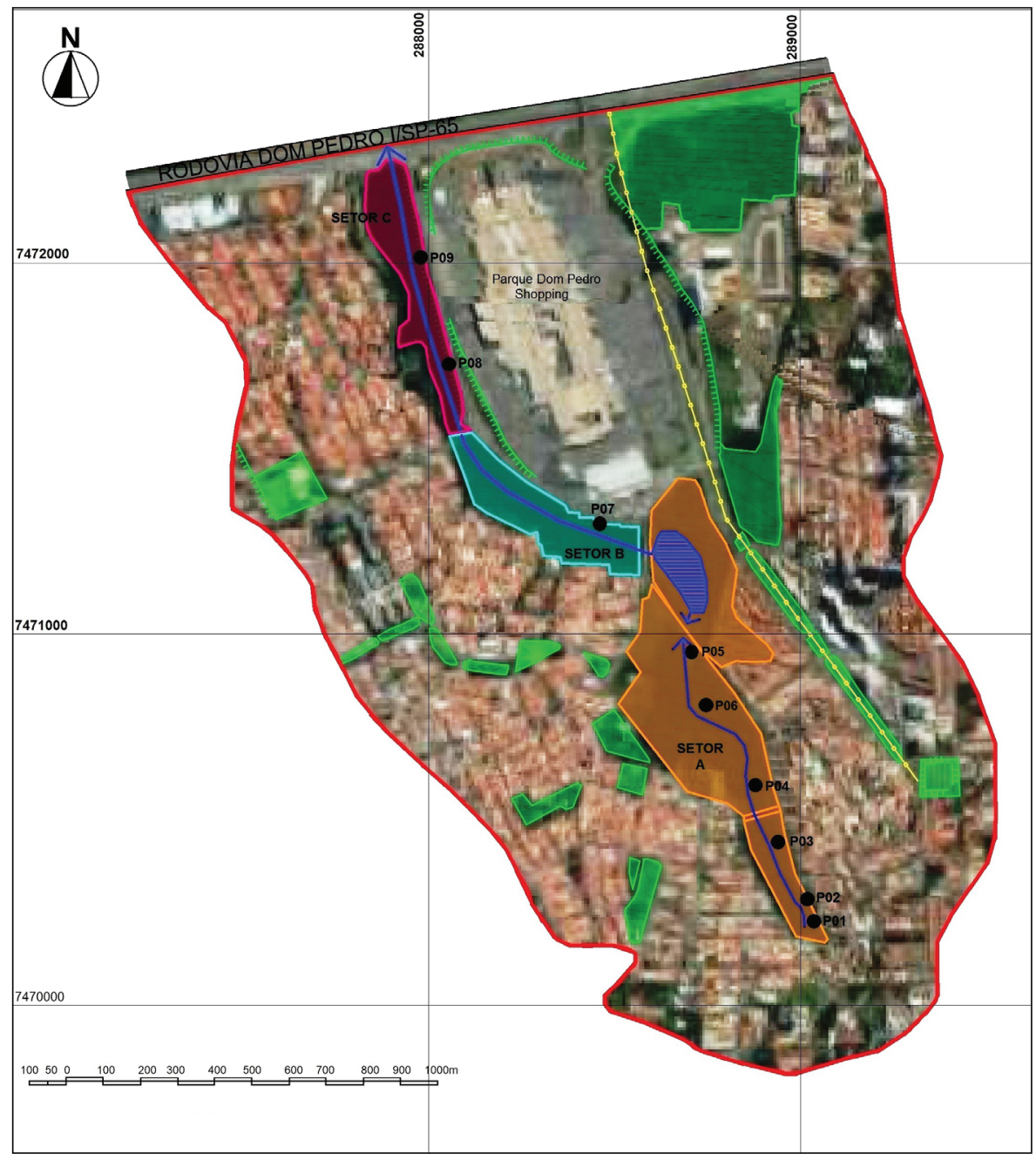

FONTE: ELABORADO A PARTIR DA IMAGEM DO GOOGLE EARTH, DATA DA IMAGAM 05/07/2017.

\section{LEGENDA}

\section{HIDROGRAFIA}

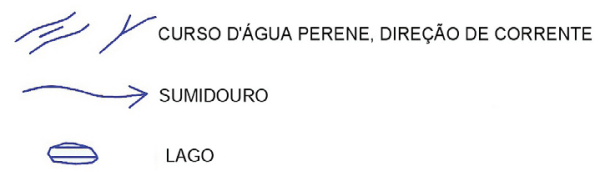

OBRAS E EDIFICAÇÕES

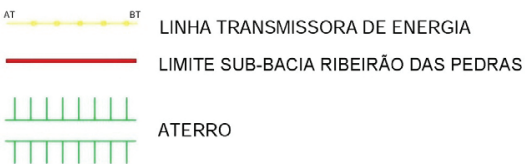

- pontos de coleta de amostras de solo

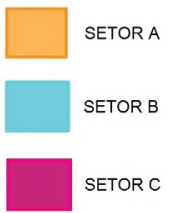

ÁREAS VERDES

FIGURA 3 - Setores A, B e C do Parque Linear Ribeirão das Pedras e pontos de amostragem de solo.

A coleta e caracterização de amostras de solo seguiram a metodologia contida no Manual de Descrição e Coleta de Solo no Campo (SANTOS et al. 2013). De acordo com esse manual, as descrições dos perfis de solo devem ser feitas durante os trabalhos de campo, incluindo a identificação dos horizontes e as descrições de suas características morfológicas: espessura, cor, textura, estrutura, consistência, transição entre horizontes, entre outras características.

Foram coletadas amostras deformadas de solo em nove pontos ao longo do Parque Linear, 
incluindo a escavação de sete trincheiras, análise e amostragem de um talude equivalente à margem direita do Ribeirão das Pedras no período de cheias e um perfil desenvolvido a partir de uma erosão linear de talude no início da pista de caminhada. A profundidade média dos pontos amostrados foi de $114 \mathrm{~cm}$ e em todos os pontos realizou-se a descrição do perfil de solo, observação de aspectos no entorno e a coleta de amostras de solo.

O histórico de uso e ocupação da área de estudo foi elaborado com base na interpretação de fotos aéreas e imagens de satélite. As fotos aéreas dos anos 1969, 1978 e 1995 foram obtidas através da empresa Base Aerofotogrametria e Projetos S.A. As imagens de satélite dos anos 2002, 2012 e 2016 foram obtidas através da ferramenta imagens históricas do Google Earth.

\subsection{Nomenclatura de horizontes de solo}

Os horizontes são camadas de solo de constituição mineral ou orgânica, aproximadamente paralelas à superfície, que sofreram a atuação dos processos físicos, químicos e biológicos responsáveis pela formação do solo, podem distinguir-se entre si através de determinadas propriedades como a cor, textura, estrutura, consistência, porosidade, nódulos e concreções minerais, etc. (IBGE 2007).

Uma vez descritas as características morfológicas dos horizontes ou camadas, procede-se a sua identificação e nomenclatura (SANTOS et al. 2013). Para a designação dos horizontes e camadas do solo, usam-se letras minúsculas, maiúsculas e números arábicos. Os números arábicos indicam a sequência de camadas sobrepostas em profundidade no perfil de solo. Podem ser usados antes ou depois das letras maiúsculas e minúsculas, com diferentes significados. Os prefixos numéricos são usados para indicar descontinuidade litológica ou do material de origem (Ex.: 1A, 2A, $2 \mathrm{C}, 2 \mathrm{Cg}$, etc.); os sufixos numéricos são usados para subdivisão de horizontes principais em profundidade (Ex.: A1, A2, Bt1, Bt2, etc). A divisão é feita a partir da parte superior do horizonte, de forma sucessiva, sendo o símbolo numérico colo- cado após todas as letras usadas para designar o horizonte (IBGE 2007).

3.2 Ensaios de caracterização físico-química das amostras de solo

As amostras de solo correspondentes a cada horizonte passaram pelas análises de rotina para solos, tais como análise granulométrica pelo método da pipeta e peneiramento, análise química em laboratório para a quantificação de parâmetros ligados à fertilidade para uso agrícola como quantidade de macronutrientes, percentagem de matéria orgânica, complexo adsorvente, capacidade de troca catiônica, saturação por bases e $\mathrm{pH}$, seguindo os procedimentos de CAMARGO et al. (2009). A análise química por espectrometria de fluorescência de raios X foi realizada para identificar e estabelecer as concentrações de cada elemento presente na amostra (JENKINS 1999, VENDEMIATTO \& ENZWEILER 2011).

\subsection{Valores orientadores de qualidade}

Os resultados obtidos com as análises de espectrometria de fluorescência de raios $\mathrm{X}$ das amostras de solo foram comparados com a Lista de Valores Orientadores para solo e águas subterrâneas no Estado de São Paulo (CETESB 2016), buscando relações entre os artefatos encontrados nos perfis e a qualidade dos solos.

A CETESB definiu três níveis de valores orientadores de qualidade para solos e águas subterrâneas (CETESB 2001):

- Valor de Referência de Qualidade (VRQ): indica o nível de qualidade para um solo considerado limpo ou a qualidade natural das águas subterrâneas;

- Valor de Prevenção (VP): indica uma possível alteração da qualidade natural dos solos e águas subterrâneas, com caráter preventivo e quando excedido, requer monitoramento, identificação das fontes de poluição e seu controle;

- Valor de Intervenção (VI): indica o limite de contaminação acima do qual, existe risco potencial para a saúde humana, havendo necessidade de uma ação imediata na área, a qual inclui uma investigação detalhada e a adoção de medidas emergenciais, visando a minimização das vias de exposição como a restrição do acesso de pessoas à área e suspensão do consumo de água subterrânea. Foi derivado com base em modelagem matemática de avaliação de risco. 
A tabela 1 exibe os elementos analisados neste trabalho e os valores de referência de qualidade (VRQ), prevenção (VP), e de intervenção (VI), bem como em quais artefatos podem ser encontrados.

\section{RESULTADOS}

\subsection{Histórico de uso e ocupação}

A foto aérea de 1969 em escala aproximada de 1: 20.000 (Figura 4) é a mais antiga dentre o acervo da Base Aerofotogrametria e Projetos S.A. que abrange a área de estudo. Nela é possível notar que nas proximidades do Ribeirão das Pedras o principal uso era rural, com áreas de pastagem e cultivo. Apesar de pouco urbanizada a cobertura vegetal original da região, sobretudo a mata ciliar do Ribeirão, já não existia mais.

A imagem de satélite de 2012 do Google Earth (Figura 5) apresenta uma configuração pare- cida com o que vemos atualmente na área (2017). O Parque Linear foi reflorestado e as copas das árvores estão parcialmente unidas o que indica o desenvolvimento da vegetação. Observa-se um maior número de residências, edifícios e condomínios residenciais; as áreas voltadas para o cultivo limitam-se a margem esquerda da Rodovia Dom Pedro I/SP-65.

\subsection{Classificação dos perfis de solo}

A seguir são apresentados os resultados da descrição morfológica dos horizontes, análises granulométricas, químicas de fertilidade (macronutrientes e complexo adsorvente) e por espectrometria de fluorescência de raios $\mathrm{X}$ dos nove pontos amostrados (tabelas 2 a 37). Os resultados das análises químicas por espectrometria de fluorescência de raios $\mathrm{X}$ foram comparados com a Lista de Valores Orientadores para solo e águas subterrâneas do Estado de São Paulo (CETESB 2016).

TABELA 1 - Lista de valores orientadores para solo no Estado de São Paulo e principais artefatos onde esses elementos são encontrados.

\begin{tabular}{|c|c|c|c|c|}
\hline \multirow{3}{*}{ Substância } & \multicolumn{3}{|c|}{ Solo ( $\mu \mathrm{g} / \mathrm{g}$ peso seco) } & \multirow{3}{*}{ Principais artefatos } \\
\hline & Valor de & Valor de & Valor de Intervenção (VI) & \\
\hline & $\begin{array}{c}\text { Referência de } \\
\text { Qualidade (VRQ) }\end{array}$ & $\begin{array}{l}\text { Prevenção } \\
\quad(V P)\end{array}$ & Agrícola Residencial Industrial & \\
\hline
\end{tabular}

\begin{tabular}{llllll} 
Bário & 120 & 500 & 1.300 & 7.300 & $\begin{array}{l}\text { Estabilizantes do PVC, vidros, soldas, tintas } \\
\text { brancas, tapetes, carpetes, pneus, papéis } \\
\text { especiais, cerâmica, couro. }\end{array}$ \\
\hline
\end{tabular}

\begin{tabular}{|c|c|c|c|c|c|c|}
\hline Chumbo & 17 & 72 & 150 & 240 & 4.400 & $\begin{array}{l}\text { Tintas, vernizes, esmaltes, ligas metálicas, } \\
\text { cerâmica, plástico, borracha, soldas, cabos } \\
\text { elétricos, resíduos eletrônicos (ex: baterias } \\
\text { automotivas). }\end{array}$ \\
\hline Cobre & 35 & 60 & 760 & 2.100 & 10.000 & $\begin{array}{l}\text { Tubulações hidráulicas e de gás, conectores } \\
\text { elétricos, pintura de madeiras e aços, } \\
\text { radiadores, freios de automóveis, rolamentos. }\end{array}$ \\
\hline Cromo Total & 40 & 75 & 150 & 300 & 400 & $\begin{array}{l}\text { Tijolos refratários, resistências elétricas, } \\
\text { couros, ligas metálicas (ex: aço inoxidável), } \\
\text { pigmentos amarelos. }\end{array}$ \\
\hline Níquel & 13 & 30 & 190 & 480 & 3.800 & $\begin{array}{l}\text { Pigmentos (esmaltes, vidros e cerâmicas), } \\
\text { aço inoxidável, óleos de motores, alumínios, } \\
\text { plásticos, baterias e materiais eletrônicos. }\end{array}$ \\
\hline Vanádio & 275 & - & - & - & - & $\begin{array}{l}\text { Ligas de ferro, aços resistentes e materiais } \\
\text { cerâmicos. }\end{array}$ \\
\hline Zinco & 60 & 86 & 1.900 & 7.000 & 10.000 & $\begin{array}{l}\text { Estruturas de aço galvanizadas, cerâmica, } \\
\text { borracha, tintas, vernizes, dobradiças, pisos, } \\
\text { pneus, mangueiras, cabos de aço, vergalhões, } \\
\text { pilhas, baterias. }\end{array}$ \\
\hline
\end{tabular}

- Valor não quantificado. Fonte: Valores orientadores para solo e águas Subterrâneas no Estado de São Paulo (CETESB 2016). 


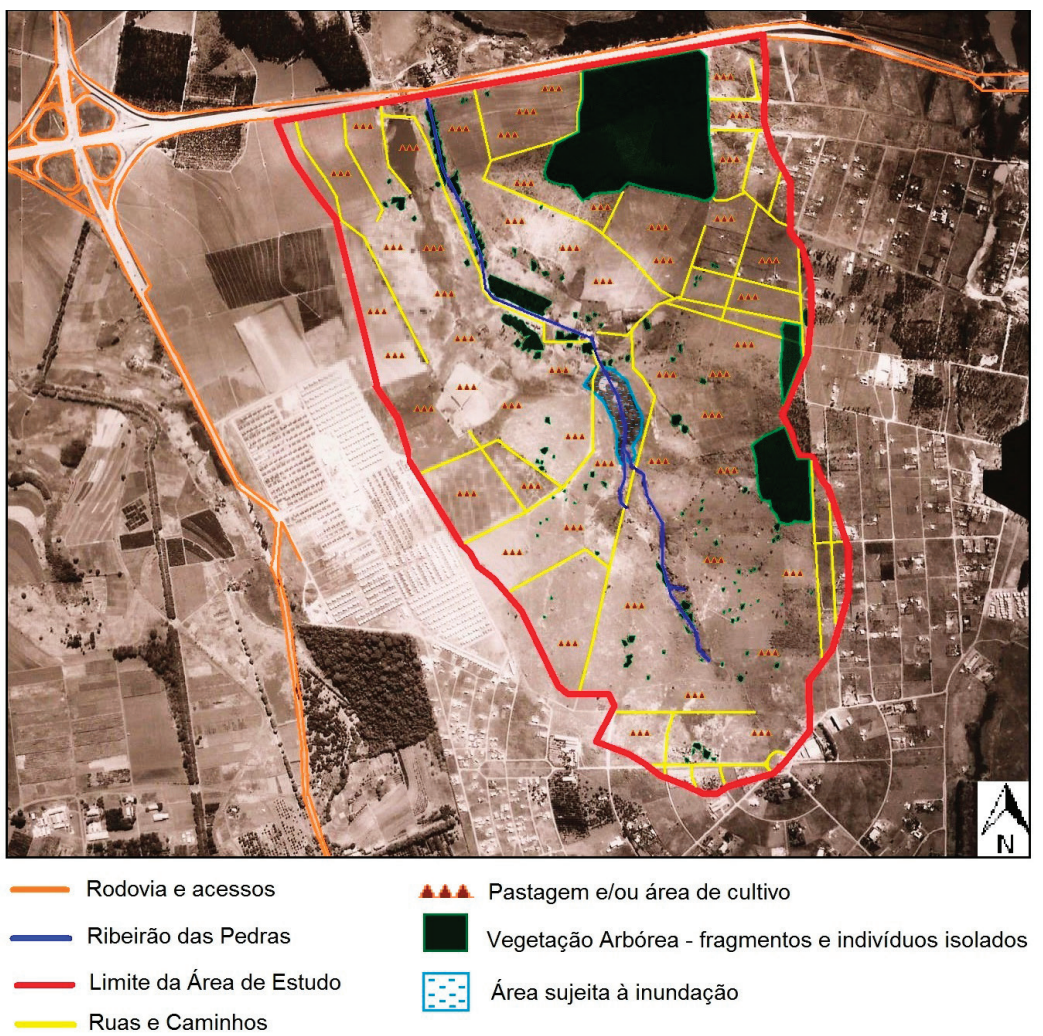

FIGURA 4 - Foto aérea de 1969. Fonte: Elaborado a partir da foto aérea obtida pela Base Aerofotogrametria e Projetos S.A. Projeto 239, Foto 121 - data do voo Maio/1969, escala aproximada 1: 20.000.

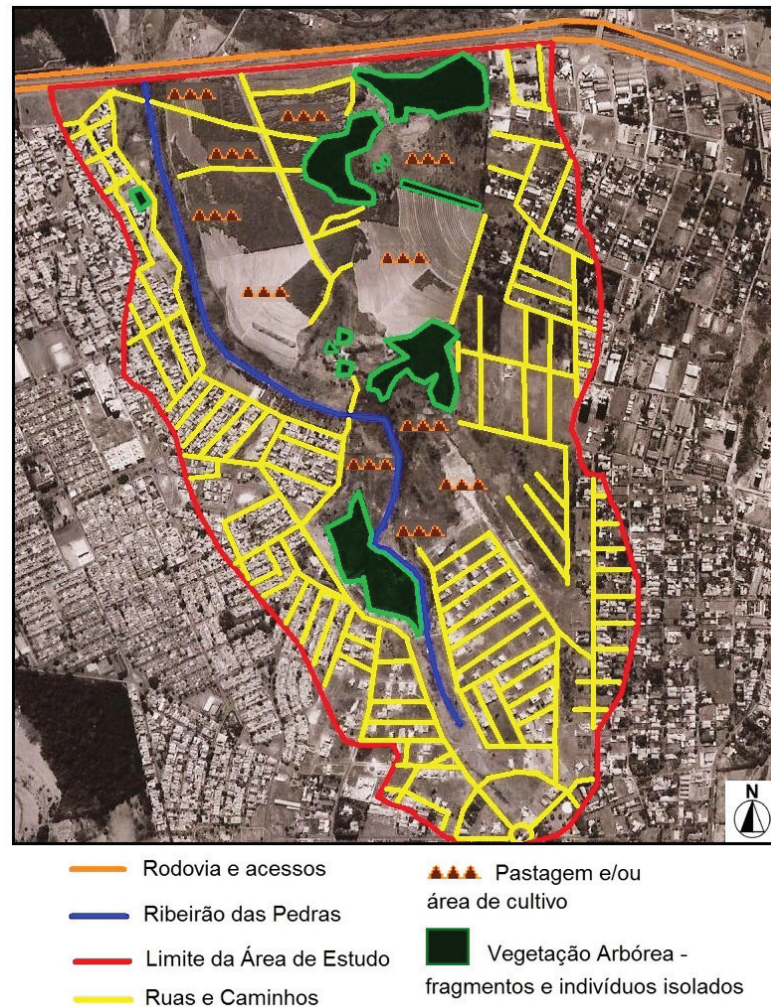

FIGURA 5 - Imagem de satélite de 2012. Fonte: Elaborado a partir da imagem de satélite obtido pelo Google Earth, data da imagem 23/12/2012. 
TABELA 2 - Descrição morfológica e particularidades do perfil de solo do ponto P01 (setor A).

\begin{tabular}{|c|c|c|}
\hline $\begin{array}{c}\text { Coordenadas: } \\
\text { 23K } 0288980 \\
7470212\end{array}$ & Data do campo: $17 / 09 / 15$ & $\begin{array}{l}\text { Classificação do solo (IUSS 2014): } \\
\text { Tecnossolo UUrbico }\end{array}$ \\
\hline
\end{tabular}

Perfil de solo do P01:

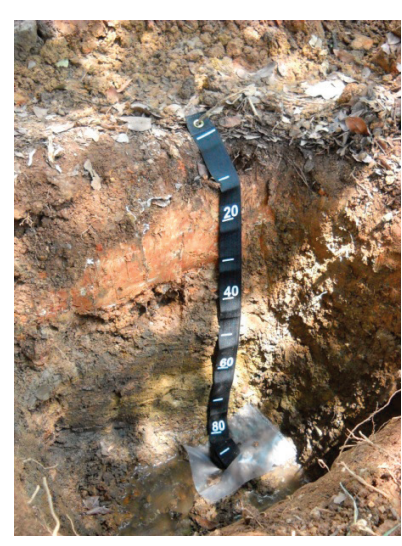

Localização:

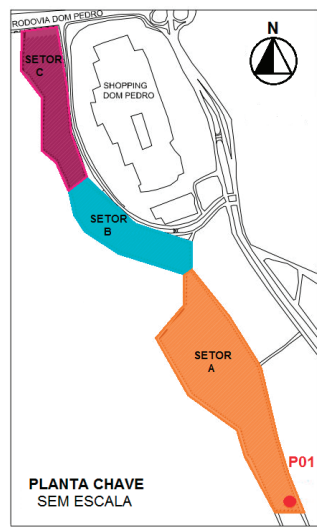

Exemplos de artefatos encontrados:

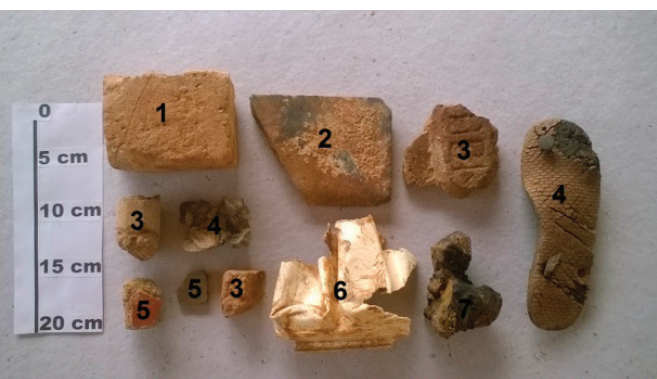

Legenda: 1- Tijolo, 2- Granito, 3- Concreto, 4- Borracha, 5- Revestimento cerâmico, 6 - Plástico, 7- Pixe.

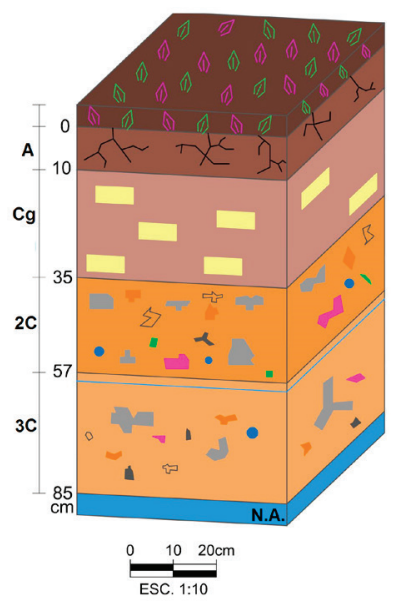

O 5-0 cm; serrapilheira constituída de folhas e galhos em diferentes graus de decomposição.

A 0-10 cm; bruno escuro (7.5R 3/6); franco argilo arenosa; fraca pequena blocos subangulares; dura, friável, plástico, pegajoso; muitos artefatos (plástico, isopor, fragmentos de tijolo), intensa atividade biológica (raízes e anelídeos - as minhocas habitam porções úmidas e com alta concentração de matéria orgânica do solo); transição plana clara.

Cg 10-35 cm; vermelho-amarelado com mosqueamento (7.5R 4/8 e 5YR 5/8); franco argilosa; maciça; macia, friável, plástico, pegajoso; poucos artefatos (plástico); transição plana clara.

$2 C$ 35-57 cm; bruno (7.5 R 3/6); franco argilo arenosa; maciça; ligeiramente duro, firme, pouco plástica, pouco pegajoso; muitos artefatos (isopor, fragmentos de cerâmica, vidro, tijolo, concreto, pixe, borracha, granito), fragmentos de basalto; transição plana gradual.

$3 C$ 57-85 cm+; bruno avermelhado (2.5YR 4/8); argilo arenosa; maciça; ligeiramente duro, firme, plástico, pouco pegajoso; muitos artefatos (isopor, borracha, plástico, fragmentos de tijolo, cerâmica e concreto).

TABELA 3 - Resultados das análises granulométricas (g/kg) do perfil de solo P01.

\begin{tabular}{|c|c|c|c|c|c|c|c|c|c|}
\hline \multirow[b]{2}{*}{$\begin{array}{c}\text { Amostra } \\
\text { P01 }\end{array}$} & \multicolumn{6}{|c|}{ AREIA (Diâmetro em milimetros) } & \multirow[b]{2}{*}{$\begin{array}{c}\text { ARGILA } \\
<0,002 \mathrm{~mm}\end{array}$} & \multirow[b]{2}{*}{$\begin{array}{c}\text { SILTE } \\
0,05-0,002 \mathrm{~mm}\end{array}$} & \multirow[b]{2}{*}{ Artefatos } \\
\hline & $\begin{array}{l}\text { Muito } \\
\text { Grossa } \\
1,0-2,0\end{array}$ & $\begin{array}{l}\text { Grossa } \\
0,5-1,0\end{array}$ & $\begin{array}{c}\text { Média } \\
0,5-0,25\end{array}$ & $\begin{array}{c}\text { Fina } \\
0,25-0,10\end{array}$ & $\begin{array}{c}\text { Muito } \\
\text { Fina } \\
0,10-0,05\end{array}$ & $\begin{array}{l}\text { AREIA } \\
\text { TOTAL }\end{array}$ & & & \\
\hline$A(0-10 \mathrm{~cm})$ & 52 & 77 & 118 & 109 & 76 & 432 & 275 & 294 & 114 \\
\hline$C g(10-35 \mathrm{~cm})$ & 03 & 08 & 22 & 31 & 23 & 87 & 337 & 576 & 35 \\
\hline $2 C(35-57 \mathrm{~cm})$ & 34 & 79 & 164 & 175 & 129 & 581 & 232 & 187 & 136 \\
\hline $3 C(57-85 \mathrm{~cm})$ & 15 & 42 & 131 & 157 & 114 & 459 & 377 & 164 & 120 \\
\hline
\end{tabular}

Classificação granulométrica americana USDA (1951). 
TABELA 4 - Resultados das análises químicas do perfil de solo P01.

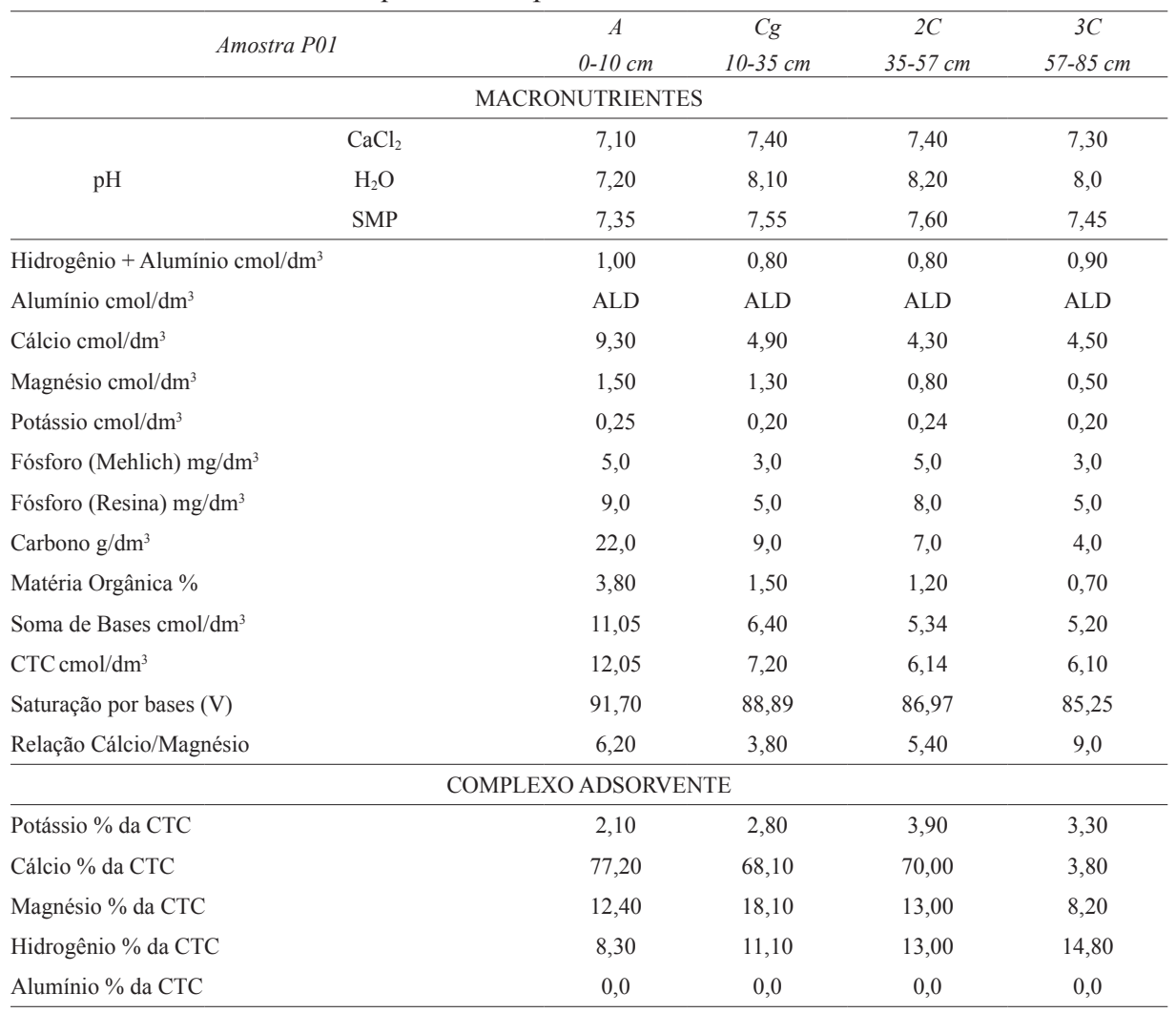

CTC: Capacidade de Troca Catiônica, ALD: Abaixo do limite deteç̧ão

TABELA 5 - Resultados da análise de espectrometria de fluorescência de raios X do perfil de solo P01. Os valores em negrito indicam concentrações acima do VRQ (CETESB 2016) para o elemento analisado, enquanto os valores em vermelho indicam concentrações acima do VP (CETESB 2016).

\begin{tabular}{|c|c|c|c|c|c|c|}
\hline Amostra P01 & $\begin{array}{c}A \\
0-10 \mathrm{~cm}\end{array}$ & $\begin{array}{c}C g \\
10-35 \mathrm{~cm}\end{array}$ & $\begin{array}{c}2 C \\
35-57 \mathrm{~cm}\end{array}$ & $\begin{array}{c}3 C \\
57-85 \mathrm{~cm}\end{array}$ & $V R Q$ & $V P$ \\
\hline \multicolumn{7}{|c|}{$\operatorname{SOMA}(\mu \mathrm{g} / \mathrm{g})$} \\
\hline Bário (Ba) & 349 & 331 & 363 & 65 & 75 & 120 \\
\hline Cério (Ce) & 61 & 47 & 58 & 13 & - & - \\
\hline Cromo $(\mathrm{Cr})$ & 43 & 47 & 42 & 62 & 40 & 75 \\
\hline Cobre $(\mathrm{Cu})$ & 33 & 12,6 & 18,6 & 16,2 & 35 & 60 \\
\hline Gálio/Gases Nobres (Ga) & 14 & 14,5 & 15,9 & 18,3 & - & - \\
\hline Lantônio (La) & 40 & 43 & 42 & 16 & - & - \\
\hline Nióbio (Nb) & 15,3 & 15,7 & 15,8 & 20 & - & - \\
\hline Neodímio $(\mathrm{Nd})$ & 24 & 32 & 36 & $<11$ & - & - \\
\hline Níquel (Ni) & $<2$ & $<2$ & $<2$ & $<2$ & 13 & 30 \\
\hline Chumbo $(\mathrm{Pb})$ & 47 & 22,6 & 44 & 12,8 & 17 & 72 \\
\hline Rubídio (Rb) & 67 & 39 & 102 & 10,7 & - & - \\
\hline Escândio (Sc) & 11 & 10 & 11 & 21 & - & - \\
\hline Estrôncio (Sr) & 75 & 38 & 73 & 16,1 & - & - \\
\hline Tório (Th) & 18,9 & 14,2 & 27,2 & 93 & - & - \\
\hline Vanádio (V) & 94 & 94 & 93 & 148 & 275 & 275 \\
\hline Ítrio $(\mathrm{Y})$ & 18 & 25,7 & 15,2 & 17,4 & - & - \\
\hline Zinco (Zn) & 64 & 26,9 & 71 & 39 & 60 & 86 \\
\hline Zircônio (Zr) & 357 & 325 & 402 & 548 & - & - \\
\hline
\end{tabular}

VRQ: Valor de Referência de Qualidade (CETESB 2016).

VP: Valor de Prevenção (CETESB 2016).

- Elemento não está presente na lista de valores orientadores para solo e águas subterrâneas do Estado de São Paulo (CETESB 2016). 
TABELA 6 - Descrição morfológica e particularidades do perfil de solo do ponto P02.

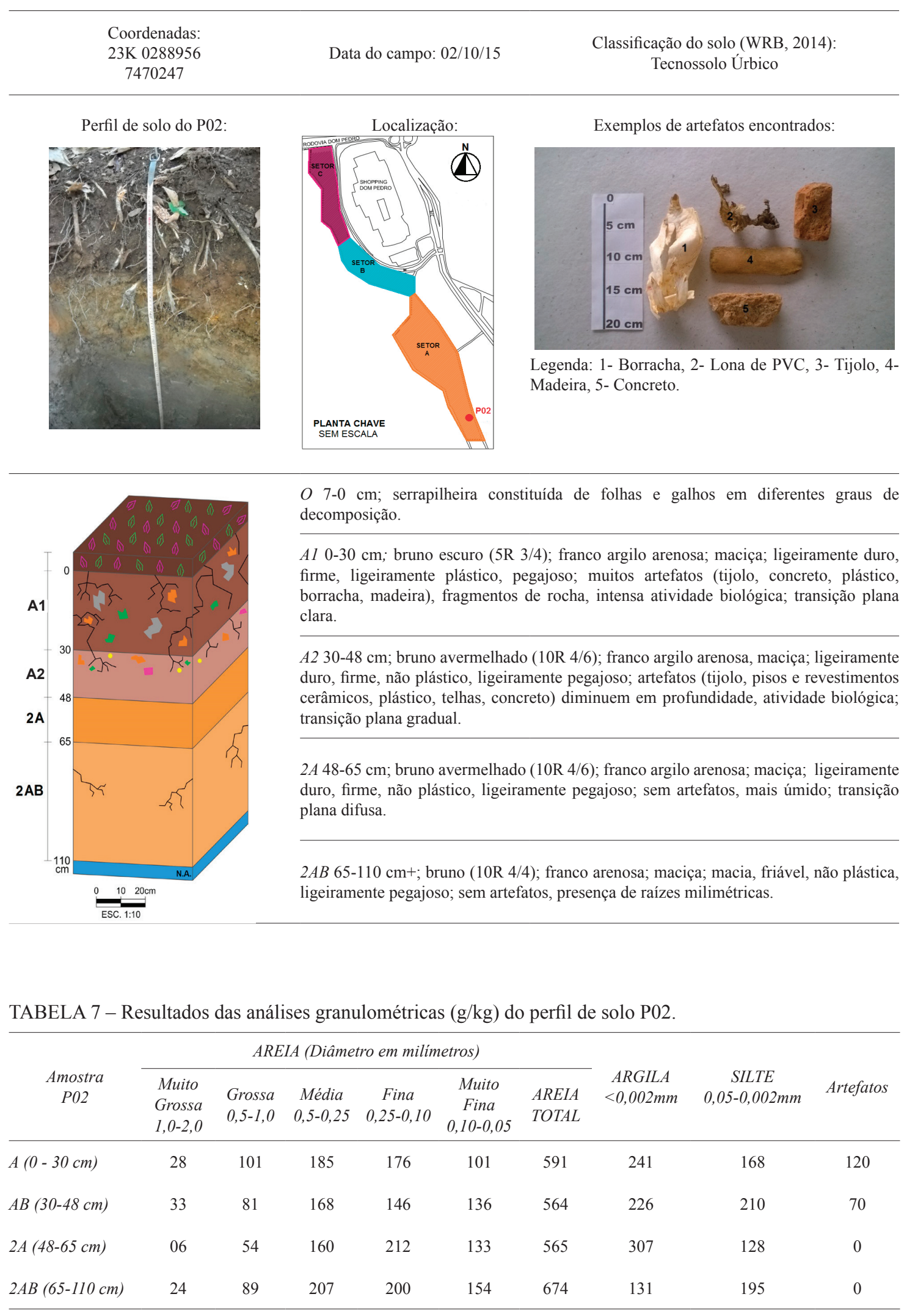

Classificação granulométrica americana USDA (1951). 
TABELA 8 - Resultados das análises químicas do perfil de solo P02.

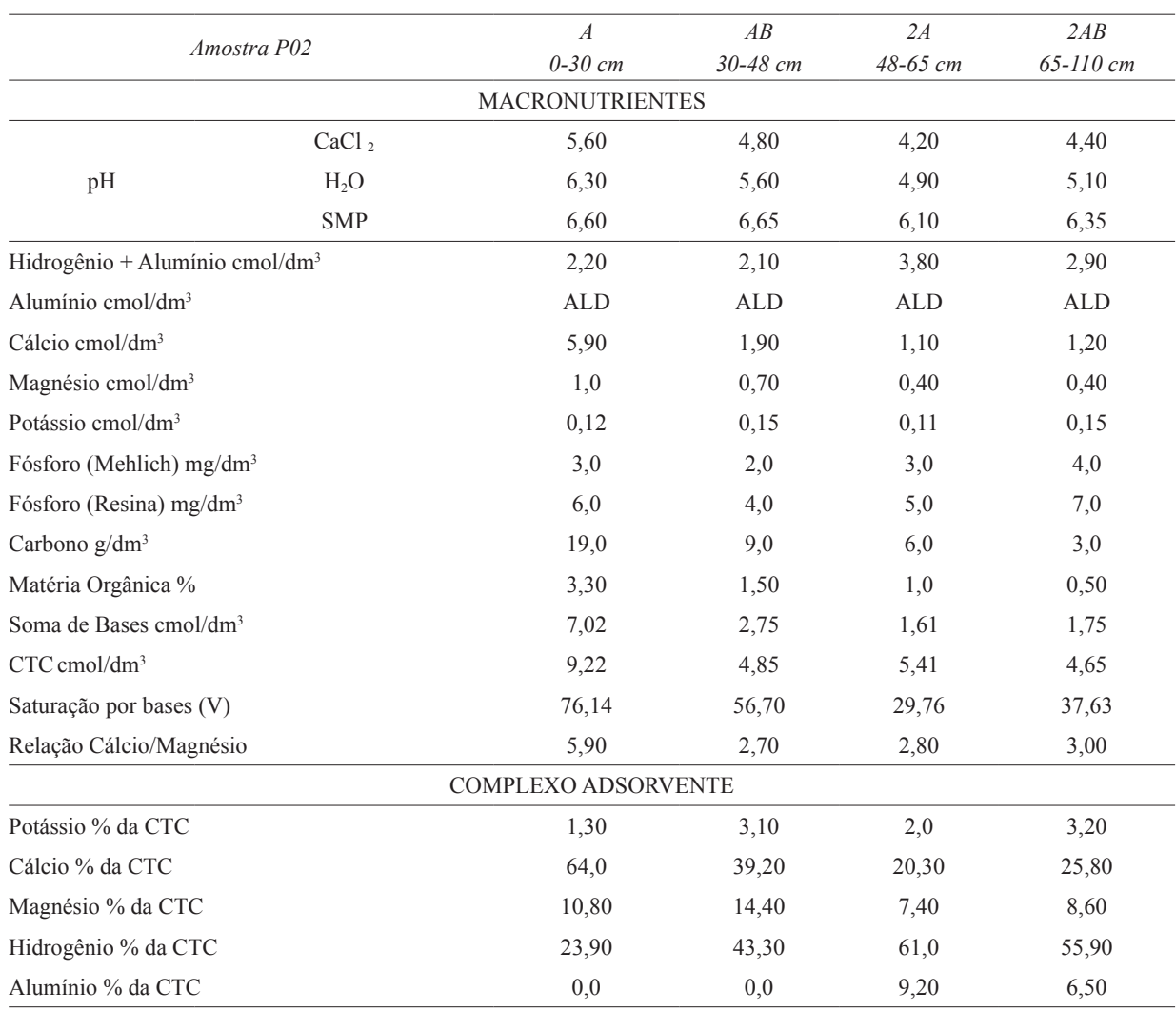

CTC: Capacidade de Troca Catiônica, ALD: Abaixo do limite detecção

TABELA 9 - Resultados da análise de espectrometria de fluorescência de raios X do perfil de solo P02. Os valores em negrito indicam concentrações acima do VRQ (CETESB 2016) para o elemento analisado, enquanto os valores em vermelho indicam concentrações acima do VP (CETESB 2016).

\begin{tabular}{|c|c|c|c|c|c|c|}
\hline Amostra P02 & $\begin{array}{c}A \\
0-30 \mathrm{~cm}\end{array}$ & $\begin{array}{c}A B \\
30-48 \mathrm{~cm}\end{array}$ & $\begin{array}{c}2 A \\
48-65 \mathrm{~cm}\end{array}$ & $\begin{array}{c}2 A B \\
65-110 \mathrm{~cm}\end{array}$ & $V R Q$ & $V P$ \\
\hline \multicolumn{7}{|c|}{$\operatorname{SOMA}(\mu \mathrm{g} / \mathrm{g})$} \\
\hline Bário (Ba) & 235 & 264 & 194 & 322 & 75 & 120 \\
\hline Cério $(\mathrm{Ce})$ & 61 & 91 & 64 & 67 & - & - \\
\hline Cromo $(\mathrm{Cr})$ & 42 & 16,4 & 41 & 13,8 & 40 & 75 \\
\hline Cobre $(\mathrm{Cu})$ & 22,6 & 6,0 & 15,7 & 4,4 & 35 & 60 \\
\hline Gálio/Gases Nobres (Ga) & 15,5 & 14,6 & 17,9 & 11,3 & - & - \\
\hline Lantônio (La) & 46 & 71 & 64 & 38 & - & - \\
\hline Nióbio (Nb) & 16,8 & 16,8 & 17,5 & 12,9 & - & - \\
\hline Neodímio (Nd) & 31 & 50 & 30 & 34 & - & - \\
\hline Níquel (Ni) & $<2$ & $<2$ & $<2$ & $<2$ & 13 & 30 \\
\hline Chumbo $(\mathrm{Pb})$ & 31 & 25,6 & 23,2 & 28,1 & 17 & 72 \\
\hline Rubídio (Rb) & 69 & 135 & 56 & 134 & - & - \\
\hline Escândio (Sc) & 14 & 07 & 14 & 03 & - & - \\
\hline Estrôncio (Sr) & 44 & 49 & 32 & 52 & - & - \\
\hline Tório (Th) & 30 & 43 & 32 & 35 & - & - \\
\hline Vanádio (V) & 126 & 56 & 123 & 26,9 & 275 & 275 \\
\hline Ítrio (Y) & 11,8 & 15,4 & 11,8 & 12,4 & - & - \\
\hline Zinco (Zn) & 83 & 32 & 32 & 24,3 & 60 & 86 \\
\hline Zircônio (Zr) & 388 & 424 & 447 & 327 & - & - \\
\hline
\end{tabular}

VRQ: Valor de Referência de Qualidade (CETESB 2016).

VP: Valor de Prevenção (CETESB 2016).

- Elemento não está presente na Lista de Valores orientadores para solo e águas subterrâneas do Estado de São Paulo (CETESB 2016). 
TABELA 10 - Descrição morfológica e particularidades do perfil de solo do ponto P03.

\begin{tabular}{|c|c|c|}
\hline $\begin{array}{c}\text { Coordenadas: } \\
\text { 23K } 0288920 \\
7470420\end{array}$ & Data do campo: $02 / 10 / 15$ & $\begin{array}{c}\text { Classificação do solo (WRB, 2014): } \\
\text { Tecnossolo Úrbico }\end{array}$ \\
\hline
\end{tabular}
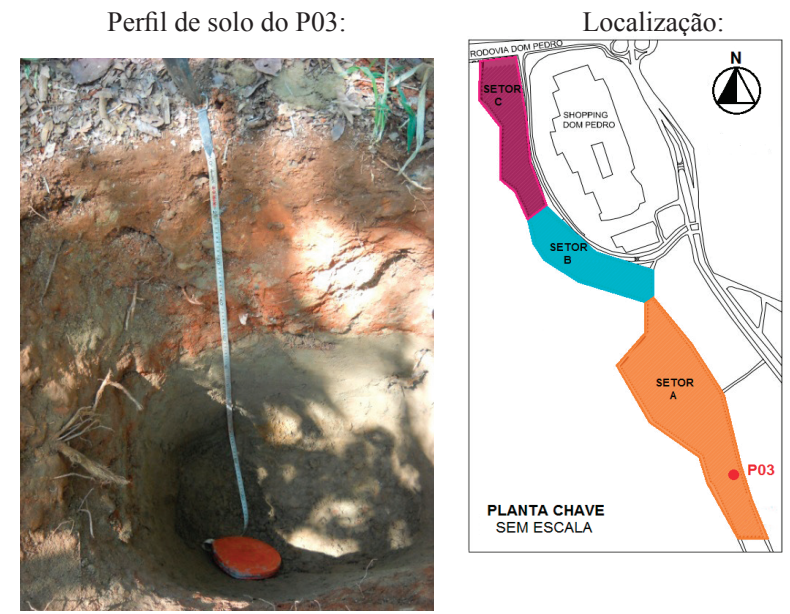

Exemplos de artefatos encontrados:

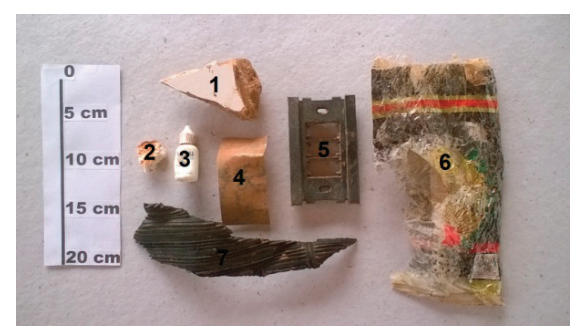

Legenda: 1- Piso cerâmico, 2- Isopor, 3- Embalagem plástica, 4- Placa metálica, 5 - Placa de plástico (interruptor de luz), 6- Embalagem plástica, 7 - Tapete automotivo.

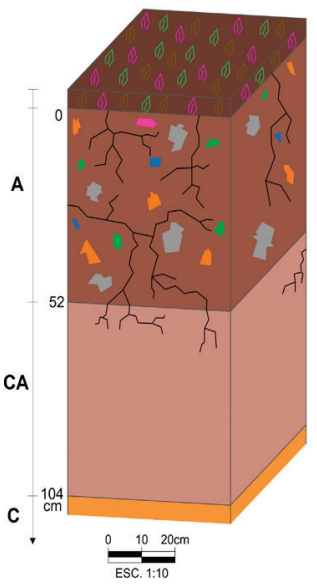

$O$ 5-0 cm; serrapilheira constituída de folhas e galhos em diferentes graus de decomposição.

A 0-52 cm; bruno avermelhado (7.5R 4/8); franca; maciça; macio, friável, não plástico, ligeiramente pegajoso; muitos artefatos (isopor, plástico, placas metálicas, revestimentos cerâmicos, cimento), fragmentos de rocha, intensa atividade biológica; transição plana clara.

CA 52-104 cm; bruno amarelado (2.5YR 5/6); franco arenosa; maciça; macio, friável, não plástico, ligeiramente pegajoso; sem artefatos, atividade biológica comum; transição plana gradual.

C $104 \mathrm{~cm} \mathrm{+;} \mathrm{bruno} \mathrm{amarelado} \mathrm{(2.5YR} \mathrm{5/8);} \mathrm{franco} \mathrm{argilo} \mathrm{arenosa;} \mathrm{maciça;} \mathrm{macio,}$ friável, não plástico, pegajoso; sem artefatos, aumento da umidade.

TABELA 11 - Resultados das análises granulométricas ( $\mathrm{g} / \mathrm{kg}$ ) do perfil de solo P03.

\begin{tabular}{|c|c|c|c|c|c|c|c|c|c|}
\hline \multirow[b]{2}{*}{$\begin{array}{c}\text { Amostra } \\
\text { P03 }\end{array}$} & \multicolumn{6}{|c|}{ AREIA (Diâmetro em milimetros) } & \multirow[b]{2}{*}{$\begin{array}{c}\text { ARGILA } \\
<0,002 \mathrm{~mm}\end{array}$} & \multirow[b]{2}{*}{$\begin{array}{c}\text { SILTE } \\
0,05-0,002 \mathrm{~mm}\end{array}$} & \multirow[b]{2}{*}{ Artefatos } \\
\hline & $\begin{array}{l}\text { Muito } \\
\text { Grossa } \\
1,0-2,0\end{array}$ & $\begin{array}{l}\text { Grossa } \\
0,5-1,0\end{array}$ & $\begin{array}{c}\text { Média } \\
0,5-0,25\end{array}$ & $\begin{array}{c}\text { Fina } \\
0,25-0,10\end{array}$ & $\begin{array}{c}\text { Muito } \\
\text { Fina } \\
0,10-0,05\end{array}$ & $\begin{array}{l}\text { AREIA } \\
\text { TOTAL }\end{array}$ & & & \\
\hline$A(0-52 \mathrm{~cm})$ & 09 & 22 & 59 & 74 & 58 & 222 & 407 & 371 & 117 \\
\hline$C A(52-104 \mathrm{~cm})$ & 30 & 127 & 212 & 144 & 124 & 637 & 113 & 250 & 0 \\
\hline$C(104 \mathrm{~cm}+)$ & 19 & 92 & 154 & 128 & 110 & 503 & 305 & 192 & 0 \\
\hline
\end{tabular}

Classificação granulométrica americana USDA (1951). 
TABELA 12 - Resultados das análises químicas do perfil de solo P03.

\begin{tabular}{|c|c|c|c|c|}
\hline \multicolumn{2}{|c|}{ Amostra P03 } & $\begin{array}{c}A \\
0-52 \mathrm{~cm} \\
\end{array}$ & $\begin{array}{c}C A \\
52-104 \mathrm{~cm}\end{array}$ & $\begin{array}{c}C \\
104 \mathrm{~cm}+\end{array}$ \\
\hline \multicolumn{5}{|c|}{ MACRONUTRIENTES } \\
\hline \multirow{3}{*}{$\mathrm{pH}$} & $\mathrm{CaCl}_{2}$ & 7,10 & 6,90 & 6,70 \\
\hline & $\mathrm{H}_{2} \mathrm{O}$ & 7,90 & 7,70 & 7,40 \\
\hline & SMP & 7,40 & 7,50 & 7,35 \\
\hline \multicolumn{2}{|c|}{ Hidrogênio + Alumínio $\mathrm{cmol} / \mathrm{dm}^{3}$} & 1,0 & 0,90 & 1,0 \\
\hline \multicolumn{2}{|c|}{ Alumínio $\mathrm{cmol} / \mathrm{dm}^{3}$} & ALD & ALD & ALD \\
\hline \multicolumn{2}{|c|}{ Cálcio $\mathrm{cmol} / \mathrm{dm}^{3}$} & 3,50 & 2,00 & 2,70 \\
\hline \multicolumn{2}{|c|}{ Magnésio $\mathrm{cmol} / \mathrm{dm}^{3}$} & 0,60 & 0,50 & 0,60 \\
\hline \multicolumn{2}{|c|}{ Potássio $\mathrm{cmol} / \mathrm{dm}^{3}$} & 0,10 & 0,15 & 0,14 \\
\hline \multicolumn{2}{|c|}{ Fósforo (Mehlich) mg/dm ${ }^{3}$} & 2,0 & 2,0 & 2,0 \\
\hline \multicolumn{2}{|c|}{ Fósforo (Resina) mg $/ \mathrm{dm}^{3}$} & 3,0 & 3,0 & 3,0 \\
\hline \multicolumn{2}{|c|}{ Carbono $\mathrm{g} / \mathrm{dm}^{3}$} & 7,0 & 4,0 & 3,0 \\
\hline \multicolumn{2}{|c|}{ Matéria Orgânica \% } & 1,20 & 0,70 & 0,50 \\
\hline \multicolumn{2}{|c|}{ Soma de Bases $\mathrm{cmol} / \mathrm{dm}^{3}$} & 4,20 & 2,65 & 3,44 \\
\hline \multicolumn{2}{|c|}{$\mathrm{CTC} \mathrm{cmol} / \mathrm{dm}^{3}$} & 5,20 & 3,55 & 4,44 \\
\hline \multicolumn{2}{|c|}{ Saturação por bases (V) } & 80,77 & 74,65 & 77,48 \\
\hline \multicolumn{2}{|c|}{ Relação Cálcio/Magnésio } & 5,80 & 4,00 & 4,50 \\
\hline \multicolumn{5}{|c|}{ COMPLEXO ADSORVENTE } \\
\hline \multicolumn{2}{|c|}{ Potássio \% da CTC } & 1,90 & 4,20 & 3,20 \\
\hline \multicolumn{2}{|c|}{ Cálcio \% da CTC } & 67,30 & 56,30 & 60,80 \\
\hline \multicolumn{2}{|c|}{ Magnésio $\%$ da CTC } & 11,50 & 14,10 & 13,50 \\
\hline \multicolumn{2}{|c|}{ Hidrogênio \% da CTC } & 19,20 & 25,40 & 22,50 \\
\hline \multicolumn{2}{|c|}{ Alumínio \% da CTC } & 0,0 & 0,0 & 0,0 \\
\hline
\end{tabular}

CTC: Capacidade de Troca Catiônica, ALD: Abaixo do limite detecção

TABELA 13 - Resultados da análise de espectrometria de fluorescência de raios X do perfil de solo P03. Os valores em negrito indicam concentrações acima do VRQ (CETESB 2016) para o elemento analisado, enquanto os valores em vermelho indicam concentrações acima do VP (CETESB 2016).

\begin{tabular}{|c|c|c|c|c|c|}
\hline Amostra P03 & $\begin{array}{c}A \\
0-52 \mathrm{~cm}\end{array}$ & $\begin{array}{c}C A \\
52-104 \mathrm{~cm}\end{array}$ & $\begin{array}{c}C \\
104 \mathrm{~cm}+\end{array}$ & $V R Q$ & $V P$ \\
\hline \multicolumn{6}{|c|}{$\operatorname{SOMA}(\mu \mathrm{g} / \mathrm{g})$} \\
\hline Bário (Ba) & 261 & 430 & 374 & 75 & 120 \\
\hline Cério (Ce) & 48 & 92 & 74 & - & - \\
\hline Cromo (Cr) & 55 & 14,3 & 25,9 & 40 & 75 \\
\hline Cobre $(\mathrm{Cu})$ & 13,4 & 2,2 & 3,8 & 35 & 60 \\
\hline Gálio/Gases Nobres (Ga) & 17,4 & 12,4 & 19,0 & - & - \\
\hline Lantônio (La) & 51 & 61 & 61 & - & - \\
\hline Nióbio (Nb) & 18,8 & 14,6 & 14,8 & - & - \\
\hline Neodímio (Nd) & 41 & 35 & 35 & - & - \\
\hline Níquel (Ni) & $<2$ & $<2$ & $<2$ & 13 & 30 \\
\hline Chumbo $(\mathrm{Pb})$ & 24,3 & 26,2 & 23,6 & 17 & 72 \\
\hline Rubídio (Rb) & 31 & 176 & 165 & - & - \\
\hline Escândio (Sc) & 14 & 04 & 06 & - & - \\
\hline Estrôncio (Sr) & 70 & 58 & 74 & - & - \\
\hline Tório (Th) & 44 & 42 & 26,5 & - & - \\
\hline Vanádio (V) & 117 & 25,6 & 56 & 275 & 275 \\
\hline Ítrio (Y) & 23,0 & 15,5 & 11,5 & - & - \\
\hline Zinco (Zn) & 32 & 25,3 & 33 & 60 & 86 \\
\hline Zircônio (Zr) & 416 & 374 & 332 & - & - \\
\hline
\end{tabular}

VRQ: Valor de Referência de Qualidade (CETESB 2016).

VP: Valor de Prevenção (CETESB 2016)

- Elemento não está presente na Lista de Valores orientadores para solo e águas subterrâneas do Estado de São Paulo (CETESB 2016). 
TABELA 14 - Descrição morfológica e particularidades do perfil de solo do ponto P04.

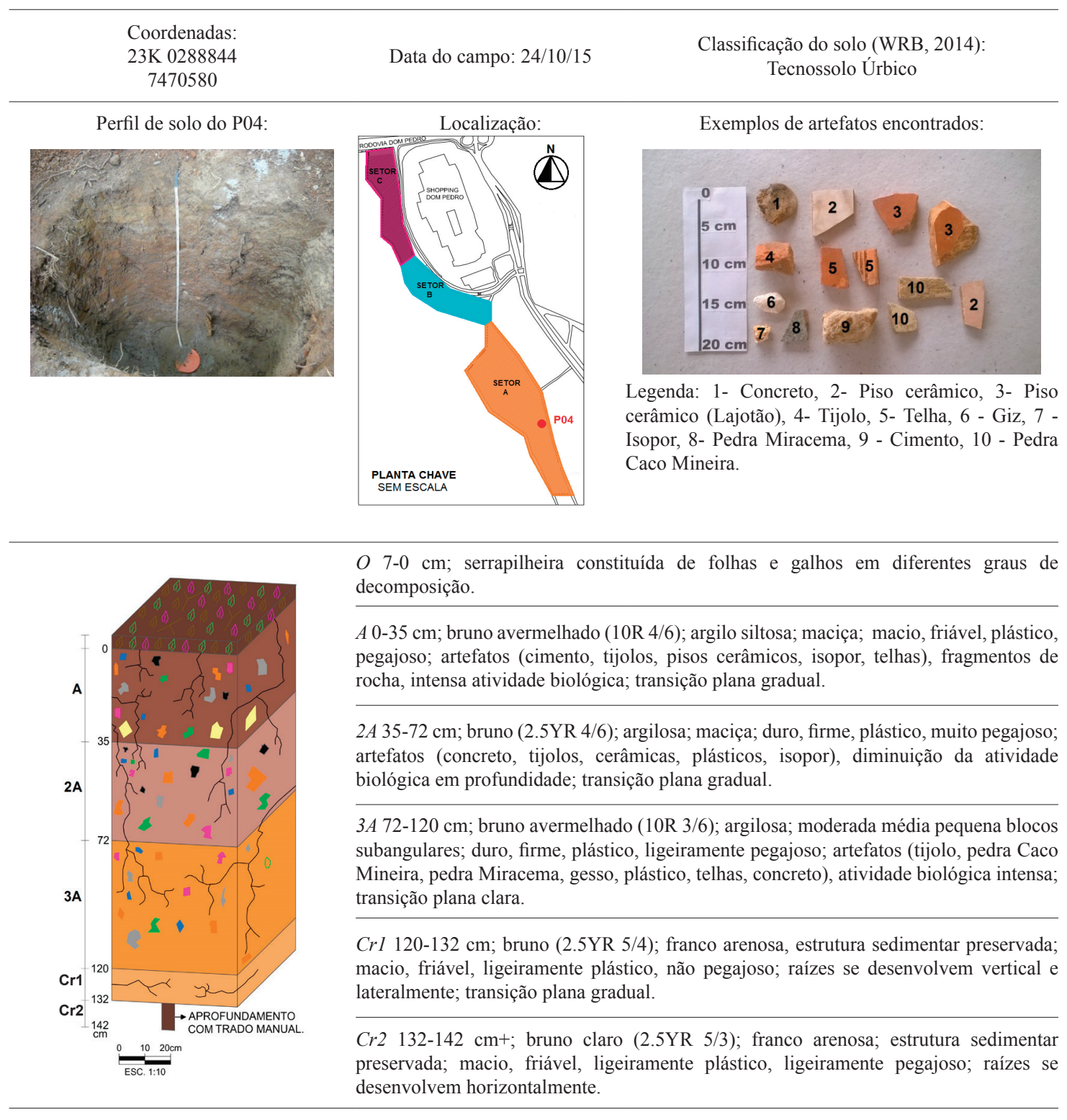

TABELA 15 - Resultados das análises granulométricas (g/kg ) do perfil de solo P04.

\begin{tabular}{ccccccccccc}
\hline \multirow{2}{*}{$\begin{array}{c}\text { Amostra } \\
\text { P04 }\end{array}$} & $\begin{array}{c}\text { Muito } \\
\text { Grossa } \\
1,0-2,0\end{array}$ & $\begin{array}{c}\text { Grossa } \\
0,5-1,0\end{array}$ & $\begin{array}{c}\text { Média } \\
0,5-0,25\end{array}$ & $\begin{array}{c}\text { Fina } \\
0,25-0,10\end{array}$ & $\begin{array}{c}\text { Muito } \\
\text { Fina } \\
\text { 0,10-0,05 }\end{array}$ & $\begin{array}{c}\text { AREIA } \\
\text { TOTAL }\end{array}$ & $\begin{array}{c}\text { ARGILA } \\
<0,002 \mathrm{~mm}\end{array}$ & $\begin{array}{c}\text { SILTE } \\
0,05-0,002 \mathrm{~mm}\end{array}$ & Artefatos \\
\hline A (0-35 cm) & 0 & 0 & 06 & 06 & 09 & 21 & 455 & 524 & 220 \\
$2 A(35-72 \mathrm{~cm})$ & 06 & 22 & 28 & 19 & 19 & 94 & 535 & 371 & 226 \\
$3 A(72-120 \mathrm{~cm})$ & 21 & 44 & 80 & 73 & 57 & 275 & 452 & 273 & 105 \\
$C(120-132 \mathrm{~cm})$ & 26 & 118 & 203 & 179 & 135 & 661 & 136 & 203 & 98 \\
$2 C(132-142 \mathrm{~cm})$ & 12 & 121 & 265 & 167 & 104 & 669 & 172 & 159 & 0 \\
\hline
\end{tabular}

Classificação granulométrica americana USDA (1951). 
TABELA 16 - Resultados das análises químicas do perfil de solo P04.

\begin{tabular}{|c|c|c|c|c|c|c|}
\hline \multicolumn{2}{|c|}{ Amostra P04 } & $\begin{array}{c}A \\
0-35 \mathrm{~cm}\end{array}$ & $\begin{array}{c}2 A \\
35-72 \mathrm{~cm}\end{array}$ & $\begin{array}{c}3 A \\
72-120 \mathrm{~cm}\end{array}$ & $\begin{array}{c}C \\
120-132 \mathrm{~cm}\end{array}$ & $\begin{array}{c}2 C \\
132-142 \mathrm{~cm}\end{array}$ \\
\hline \multicolumn{7}{|c|}{ MACRONUTRIENTES } \\
\hline \multirow{3}{*}{$\mathrm{pH}$} & $\mathrm{CaCl}_{2}$ & 3,90 & 3,80 & 5,20 & 4,40 & 4,90 \\
\hline & $\mathrm{H}_{2} \mathrm{O}$ & 4,40 & 4,30 & 5,90 & 5,10 & 5,70 \\
\hline & SMP & 5,25 & 5,10 & 6,35 & 6,15 & 6,80 \\
\hline \multicolumn{2}{|c|}{ Hidrogênio + Alumínio $\mathrm{cmol} / \mathrm{dm}^{3}$} & 9,30 & 10,90 & 8,90 & 3,60 & 1,80 \\
\hline \multicolumn{2}{|c|}{ Alumínio $\mathrm{cmol} / \mathrm{dm}^{3}$} & 2,0 & 2,10 & ALD & 0,40 & ALD \\
\hline \multicolumn{2}{|c|}{ Cálcio $\mathrm{cmol} / \mathrm{dm}^{3}$} & 1,90 & 1,60 & 4,80 & 1,50 & 2,10 \\
\hline \multicolumn{2}{|c|}{ Magnésio $\mathrm{cmol} / \mathrm{dm}^{3}$} & 0,60 & 0,50 & 0,90 & 0,40 & 0,60 \\
\hline \multicolumn{2}{|c|}{ Potássio $\mathrm{cmol} / \mathrm{dm}^{3}$} & 0,39 & 0,37 & 0,23 & 0,12 & 0,17 \\
\hline \multicolumn{2}{|c|}{ Fósforo (Mehlich) $\mathrm{mg} / \mathrm{dm}^{3}$} & 7,0 & 6,0 & 5,0 & 5,0 & 3,0 \\
\hline \multicolumn{2}{|c|}{ Fósforo (Resina) $\mathrm{mg} / \mathrm{dm}^{3}$} & 14,0 & 11,0 & 9,0 & 10,0 & 5,0 \\
\hline \multicolumn{2}{|c|}{ Carbono $\mathrm{g} / \mathrm{dm}^{3}$} & 16,0 & 12,0 & 10,0 & 5,0 & 3,0 \\
\hline \multicolumn{2}{|c|}{ Matéria Orgânica \% } & 2,80 & 2,10 & 1,70 & 0,90 & 0,50 \\
\hline \multicolumn{2}{|c|}{ Soma de Bases cmol/ $/ \mathrm{dm}^{3}$} & 2,89 & 2,47 & 5,93 & 2,02 & 2,87 \\
\hline \multicolumn{2}{|c|}{$\mathrm{CTC} \mathrm{cmol} / \mathrm{dm}^{3}$} & 12,19 & 13,37 & 8,83 & 5,62 & 4,67 \\
\hline \multicolumn{2}{|c|}{ Saturação por bases (V) } & 23,71 & 18,47 & 67,16 & 35,94 & 61,46 \\
\hline \multicolumn{2}{|c|}{ Relação Cálcio/Magnésio } & 3,20 & 3,20 & 5,30 & 3,80 & 3,50 \\
\hline \multicolumn{7}{|c|}{ COMPLEXO ADSORVENTE } \\
\hline \multicolumn{2}{|c|}{ Potássio \% da CTC } & 3,20 & 2,80 & 2,60 & 2,10 & 3,60 \\
\hline \multicolumn{2}{|c|}{ Cálcio \% da CTC } & 15,60 & 12,00 & 54,40 & 26,70 & 45,00 \\
\hline \multicolumn{2}{|c|}{ Magnésio \% da CTC } & 4,90 & 3,70 & 10,20 & 7,10 & 12,80 \\
\hline \multicolumn{2}{|c|}{ Hidrogênio \% da CTC } & 59,90 & 65,80 & 32,80 & 56,90 & 38,50 \\
\hline \multicolumn{2}{|c|}{ Alumínio \% da CTC } & 16,40 & 15,70 & 0,0 & 7,10 & 0,0 \\
\hline
\end{tabular}

CTC: Capacidade de Troca Catiônica, ALD: Abaixo do limite detecção

TABELA 17 - Resultados da análise de espectrometria de fluorescência de raios X do perfil de solo P04. Os valores em negrito indicam concentrações acima do VRQ (CETESB 2016) para o elemento analisado, enquanto os valores em vermelho indicam concentrações acima do VP (CETESB 2016).

\begin{tabular}{|c|c|c|c|c|c|c|c|}
\hline Amostra P04 & $\begin{array}{c}A \\
0-35 \mathrm{~cm}\end{array}$ & $\begin{array}{c}2 A \\
35-72 \mathrm{~cm}\end{array}$ & $\begin{array}{c}3 A \\
72-120 \mathrm{~cm}\end{array}$ & $\begin{array}{c}C \\
120-132 \mathrm{~cm}\end{array}$ & $\begin{array}{c}2 C \\
132-142 \mathrm{~cm}\end{array}$ & $V R Q$ & $V P$ \\
\hline \multicolumn{8}{|c|}{ SOMA $(\mu \mathrm{g} / \mathrm{g})$} \\
\hline Bário (Ba) & 568 & 468 & 404 & 375 & 307 & 75 & 120 \\
\hline Cério $(\mathrm{Ce})$ & 99 & 84 & 78 & 98 & 60 & - & - \\
\hline Cromo $(\mathrm{Cr})$ & 27,1 & 48 & $\mathbf{5 0}$ & 28,9 & 37 & 40 & 75 \\
\hline Cobre $(\mathrm{Cu})$ & 43 & 97 & 85 & 11,3 & 4,8 & 35 & 60 \\
\hline Gálio/Gases Nobres (Ga) & 29 & 26,9 & 21,5 & 11,3 & 12,4 & - & - \\
\hline Lantônio (La) & 94 & 68 & 70 & 74 & 56 & - & - \\
\hline Nióbio (Nb) & 19,3 & 19,4 & 18,1 & 14,7 & 12,7 & - & - \\
\hline Neodímio (Nd) & 73 & 63 & 49 & 44 & 30 & - & - \\
\hline Níquel (Ni) & $<2$ & $<2$ & $<2$ & $<2$ & $<2$ & 13 & 30 \\
\hline Chumbo $(\mathrm{Pb})$ & 47 & 41 & 32 & 22,3 & 19,9 & 17 & 72 \\
\hline Rubídio (Rb) & 291 & 193 & 131 & 112 & 88 & - & - \\
\hline Escândio (Sc) & 16 & 38 & 35 & 04 & 05 & - & - \\
\hline Estrôncio (Sr) & 74 & 55 & 60 & 62 & 50 & - & - \\
\hline Tório (Th) & 26,5 & 24,1 & 26,8 & 47 & 36 & - & - \\
\hline Vanádio (V) & 142 & 289 & 249 & 48 & 39 & 275 & 275 \\
\hline Ítrio (Y) & 26 & 27,2 & 22,8 & 12,3 & 10,7 & - & - \\
\hline Zinco (Zn) & 85 & 81 & 78 & 27,1 & 22,7 & 60 & 86 \\
\hline Zircônio (Zr) & 148 & 221 & 277 & 442 & 348 & - & - \\
\hline
\end{tabular}

VRQ: Valor de Referência de Qualidade (CETESB 2016).

VP: Valor de Prevenção (CETESB 2016).

- Elemento não está presente na lista de valores orientadores para solo e águas subterrâneas do Estado de São Paulo (CETESB 2016). 
TABELA 18 - Descrição morfológica e particularidades do perfil de solo do ponto P05.
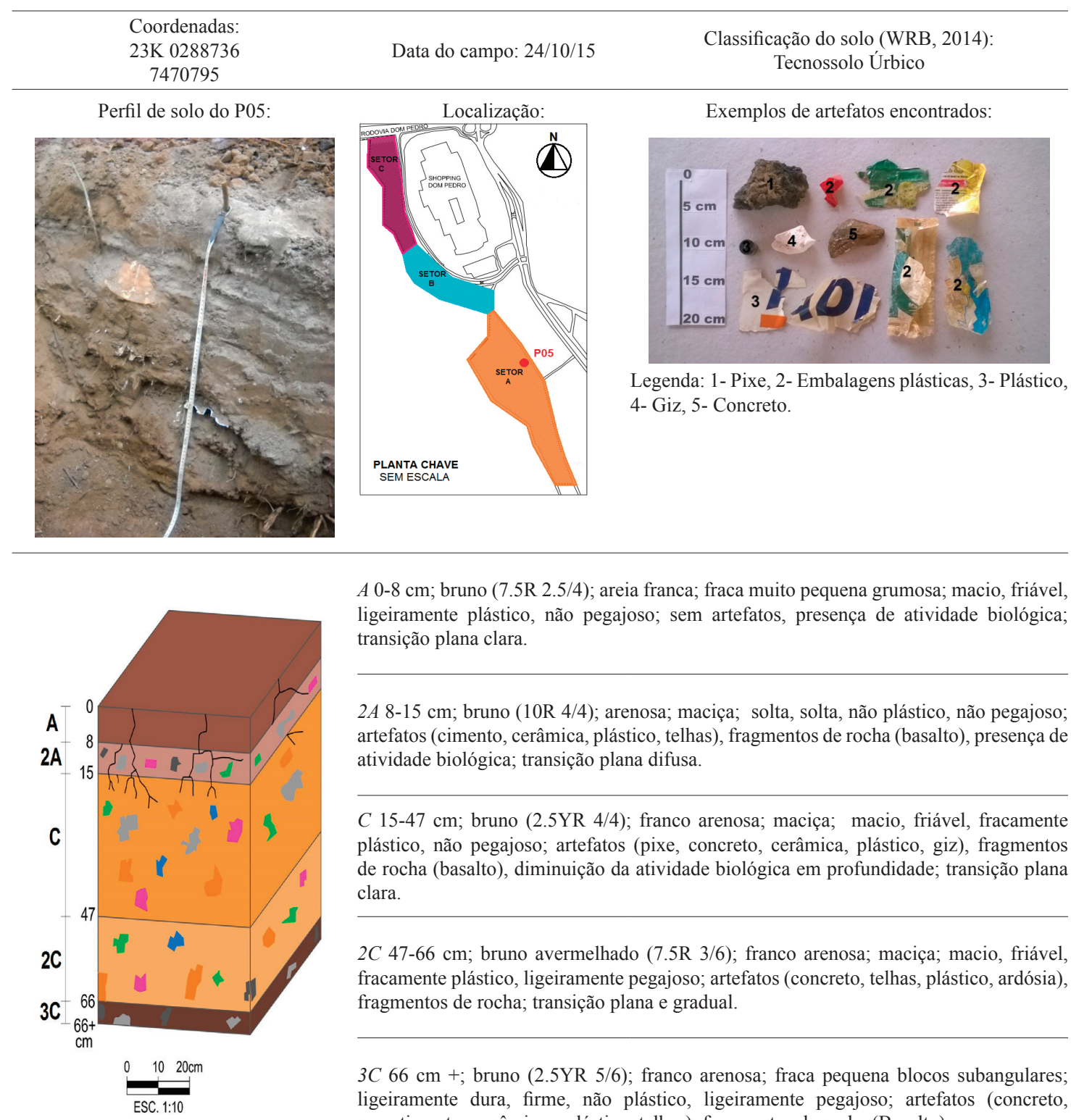

A 0-8 cm; bruno (7.5R 2.5/4); areia franca; fraca muito pequena grumosa; macio, friável, ligeiramente plástico, não pegajoso; sem artefatos, presença de atividade biológica; transição plana clara.

$2 A$ 8-15 cm; bruno (10R 4/4); arenosa; maciça; solta, solta, não plástico, não pegajoso; artefatos (cimento, cerâmica, plástico, telhas), fragmentos de rocha (basalto), presença de atividade biológica; transição plana difusa.

C 15-47 cm; bruno (2.5YR 4/4); franco arenosa; maciça; macio, friável, fracamente plástico, não pegajoso; artefatos (pixe, concreto, cerâmica, plástico, giz), fragmentos de rocha (basalto), diminuição da atividade biológica em profundidade; transição plana clara.

$2 C$ 47-66 cm; bruno avermelhado (7.5R 3/6); franco arenosa; maciça; macio, friável, fracamente plástico, ligeiramente pegajoso; artefatos (concreto, telhas, plástico, ardósia), fragmentos de rocha; transição plana e gradual.

$3 C 66 \mathrm{~cm}+$; bruno (2.5YR 5/6); franco arenosa; fraca pequena blocos subangulares; ligeiramente dura, firme, não plástico, ligeiramente pegajoso; artefatos (concreto, revestimentos cerâmicos, plástico, telhas), fragmentos de rocha (Basalto).

TABELA 19 - Resultados das análises granulométricas (g/kg) do perfil de solo P05.

\begin{tabular}{|c|c|c|c|c|c|c|c|c|c|}
\hline \multirow[b]{2}{*}{$\begin{array}{l}\text { Amostra } \\
\text { P05 }\end{array}$} & \multicolumn{6}{|c|}{ AREIA (Diâmetro em milimetros) } & \multirow[b]{2}{*}{$\begin{array}{c}\text { ARGILA } \\
<0,002 \mathrm{~mm}\end{array}$} & \multirow[b]{2}{*}{$\begin{array}{c}\text { SILTE } \\
0,05-0,002 \mathrm{~mm}\end{array}$} & \multirow[b]{2}{*}{ Artefatos } \\
\hline & $\begin{array}{l}\text { Muito } \\
\text { Grossa } \\
1,0-2,0\end{array}$ & $\begin{array}{l}\text { Grossa } \\
0,5-1,0\end{array}$ & $\begin{array}{c}\text { Média } \\
0,5-0,25\end{array}$ & $\begin{array}{c}\text { Fina } \\
0,25-0,10\end{array}$ & $\begin{array}{c}\text { Muito } \\
\text { Fina } \\
0,10-0,05\end{array}$ & $\begin{array}{l}\text { AREIA } \\
\text { TOTAL }\end{array}$ & & & \\
\hline$A(0-08 \mathrm{~cm})$ & 22 & 57 & 250 & 282 & 171 & 782 & 98 & 120 & 0 \\
\hline $2 A(08-15 \mathrm{~cm})$ & 09 & 141 & 425 & 249 & 75 & 899 & 61 & 40 & 245 \\
\hline$C(15-47 \mathrm{~cm})$ & 16 & 20 & 99 & 317 & 271 & 723 & 132 & 145 & 202 \\
\hline $2 C(47-66 \mathrm{~cm})$ & 68 & 211 & 257 & 148 & 78 & 762 & 129 & 109 & 107 \\
\hline $3 C(66 \mathrm{~cm}+)$ & 52 & 88 & 122 & 218 & 181 & 661 & 191 & 148 & 79 \\
\hline
\end{tabular}


TABELA 20 - Resultados das análises químicas do perfil de solo P05.

\begin{tabular}{|c|c|c|c|c|c|c|}
\hline \multicolumn{2}{|c|}{ Amostra P05 } & $\begin{array}{c}A \\
0-08 \mathrm{~cm}\end{array}$ & $\begin{array}{c}2 A \\
08-15 \mathrm{~cm}\end{array}$ & $\begin{array}{c}C \\
15-47 \mathrm{~cm} \\
\end{array}$ & $\begin{array}{c}2 C \\
47-66 \mathrm{~cm} \\
\end{array}$ & $\begin{array}{c}3 C \\
66 \mathrm{~cm}+\end{array}$ \\
\hline \multicolumn{7}{|c|}{ MACRONUTRIENTES } \\
\hline \multirow{3}{*}{$\mathrm{pH}$} & $\mathrm{CaCl}_{2}$ & 6,10 & 6,10 & 5,70 & 6,00 & 6,10 \\
\hline & $\mathrm{H}_{2} \mathrm{O}$ & 6,80 & 6,90 & 6,50 & 6,80 & 6,90 \\
\hline & SMP & 7,15 & 7,30 & 7,00 & 7,05 & 7,20 \\
\hline \multicolumn{2}{|c|}{ Hidrogênio + Alumínio $\mathrm{cmol} / \mathrm{dm}^{3}$} & 1,30 & 1,10 & 1,50 & 1,40 & 1,20 \\
\hline \multicolumn{2}{|c|}{ Alumínio $\mathrm{cmol} / \mathrm{dm}^{3}$} & ALD & ALD & ALD & ALD & ALD \\
\hline \multicolumn{2}{|c|}{ Cálcio $\mathrm{cmol} / \mathrm{dm}^{3}$} & 3,70 & 2,0 & 3,90 & 5,0 & 3,80 \\
\hline \multicolumn{2}{|c|}{ Magnésio cmol/ $/ \mathrm{dm}^{3}$} & 0,80 & 0,60 & 1,00 & 1,10 & 1,00 \\
\hline \multicolumn{2}{|c|}{ Potássio $\mathrm{cmol} / \mathrm{dm}^{3}$} & 0,42 & 0,31 & 0,30 & 0,27 & 0,25 \\
\hline \multicolumn{2}{|c|}{ Fósforo (Mehlich) mg/dm ${ }^{3}$} & 26,0 & 22,0 & 17,0 & 5,0 & 6,0 \\
\hline \multicolumn{2}{|c|}{ Fósforo (Resina) $\mathrm{mg} / \mathrm{dm}^{3}$} & 39,0 & 31,0 & 24,0 & 8,0 & 9,0 \\
\hline \multicolumn{2}{|c|}{ Carbono $\mathrm{g} / \mathrm{dm}^{3}$} & 15,0 & 10,0 & 8,0 & 6,0 & 3,0 \\
\hline \multicolumn{2}{|c|}{ Matéria Orgânica \% } & 2,60 & 1,70 & 1,40 & 1,00 & 0,50 \\
\hline \multicolumn{2}{|c|}{ Soma de Bases $\mathrm{cmol} / \mathrm{dm}^{3}$} & 4,92 & 2,91 & 5,20 & 6,37 & 5,05 \\
\hline \multicolumn{2}{|c|}{$\mathrm{CTC} \mathrm{cmol} / \mathrm{dm}^{3}$} & 6,22 & 4,01 & 6,70 & 7,77 & 6,25 \\
\hline \multicolumn{2}{|c|}{ Saturação por bases (V) } & 79,10 & 72,57 & 77,61 & 81,98 & 80,80 \\
\hline \multicolumn{2}{|c|}{ Relação Cálcio/Magnésio } & 4,60 & 3,30 & 3,90 & 4,50 & 3,80 \\
\hline \multicolumn{7}{|c|}{ COMPLEXO ADSORVENTE } \\
\hline \multicolumn{2}{|c|}{ Potássio \% da CTC } & 6,80 & 7,70 & 4,50 & 3,50 & 4,0 \\
\hline \multicolumn{2}{|c|}{ Cálcio \% da CTC } & 59,50 & 49,90 & 58,20 & 64,40 & 60,80 \\
\hline \multicolumn{2}{|c|}{ Magnésio \% da CTC } & 12,90 & 15,00 & 14,90 & 14,20 & 16,0 \\
\hline \multicolumn{2}{|c|}{ Hidrogênio \% da CTC } & 20,90 & 27,40 & 22,40 & 18,00 & 19,20 \\
\hline \multicolumn{2}{|c|}{ Alumínio \% da CTC } & 0,0 & 0,0 & 0,0 & 0,0 & 0,0 \\
\hline
\end{tabular}

CTC: Capacidade de Troca Catiônica, ALD: Abaixo do limite detecção

TABELA 21 - Resultados da análise de espectrometria de fluorescência de raios X do perfil de solo P05. Os valores em negrito indicam concentrações acima do VRQ (CETESB 2016) para o elemento analisado, enquanto os valores em vermelho indicam concentrações acima do VP (CETESB 2016).

\begin{tabular}{|c|c|c|c|c|c|c|c|}
\hline Amostra P05 & $\begin{array}{c}A \\
0-08 \mathrm{~cm}\end{array}$ & $\begin{array}{c}2 A \\
08-15 \mathrm{~cm}\end{array}$ & $\begin{array}{c}C \\
15-47 \mathrm{~cm}\end{array}$ & $\begin{array}{c}2 C \\
47-66 \mathrm{~cm}\end{array}$ & $\begin{array}{c}3 C \\
66 \mathrm{~cm}+\end{array}$ & $V R Q$ & $V P$ \\
\hline \multicolumn{8}{|c|}{$\operatorname{SOMA}(\mu \mathrm{g} / \mathrm{g})$} \\
\hline Bário (Ba) & 411 & 315 & 476 & 647 & 462 & 75 & 120 \\
\hline Cério (Ce) & 74 & 50 & 90 & 75 & 92 & - & - \\
\hline Cromo (Cr) & 18,2 & 51 & 27,5 & 65 & 56 & 40 & 75 \\
\hline Cobre $(\mathrm{Cu})$ & 13,4 & 6,7 & 20,4 & 36 & 40 & 35 & 60 \\
\hline Gálio/Gases Nobres (Ga) & 9,5 & 7,7 & 13,9 & 13,3 & 14,9 & - & - \\
\hline Lantônio (La) & 62 & 26 & 63 & 41 & 82 & - & - \\
\hline Nióbio (Nb) & 12,8 & 8,5 & 15,0 & 12,8 & 15,2 & - & - \\
\hline Neodímio (Nd) & 35 & 26 & 36 & 34 & 50 & - & - \\
\hline Níquel (Ni) & $<2$ & $<2$ & $<2$ & 2,8 & $<2$ & 13 & 30 \\
\hline Chumbo $(\mathrm{Pb})$ & 26,9 & 20,9 & 35 & 35 & 32 & 17 & 72 \\
\hline Rubídio (Rb) & 122 & 88 & 141 & 156 & 127 & - & - \\
\hline Escândio (Sc) & 06 & 03 & 08 & 12 & 13 & - & - \\
\hline Estrôncio (Sr) & 82 & 60 & 91 & 117 & 86 & - & - \\
\hline Tório (Th) & 41 & 23,60 & 42 & 22,5 & 40 & - & - \\
\hline Vanádio (V) & 50 & 41 & 80 & 142 & 154 & 275 & 275 \\
\hline Ítrio (Y) & 11,1 & 6,0 & 14,2 & 13,7 & 16,8 & - & - \\
\hline Zinco (Zn) & 43 & 25,6 & 61 & 51 & 57 & 60 & 86 \\
\hline Zircônio (Zr) & 333 & 183 & 447 & 246 & 340 & - & - \\
\hline
\end{tabular}

VRQ: Valor de Referência de Qualidade (CETESB 2016).

VP: Valor de Prevenção (CETESB 2016).

- Elemento não está presente na lista de valores orientadores para solo e águas subterrâneas do Estado de São Paulo (CETESB 2016). 
TABELA 22 - Descrição morfológica e particularidades do perfil de solo do ponto P06.

$\begin{gathered}\text { Coordenadas: } \\ \text { 23K 0288654 } \\ 7470949\end{gathered}$
Perfil de solo do P06: $\begin{gathered}\begin{array}{c}\text { Classificação do solo (WRB, 2014): } \\ \text { Tecnossolo Úrbico }\end{array} \\ \text { Exemplos de artefatos encontrados: }\end{gathered}$

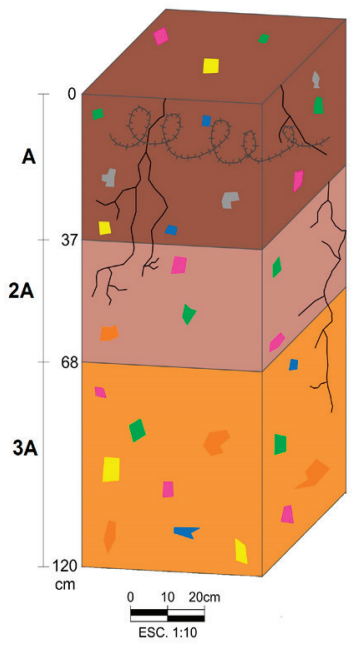

A 0-37 cm; bruno (2.5YR 4/6); franco arenosa; fraca pequena blocos subangulares; macio, friável, não plástico, não pegajoso; artefatos (arame farpado, plástico, caixas de papel), fragmentos de rocha, atividade biológica intensa; transição plana clara.

2A 37-68 cm; bruno (10R 4/6); franco arenosa; fraca pequena blocos subangulares; macio, friável, não plástico, não pegajoso; artefatos (plástico, revestimentos cerâmicos, madeira), atividade biológica intensa; transição plana gradual.

3 A 68-120 cm+; bruno (10R 4/4); franco argilosa; maciça; ligeiramente dura, friável, plástico, pegajoso; artefatos (cimento, tijolos, plásticos, revestimentos cerâmicos), atividade biológica diminui em profundidade.

TABELA 23 - Resultados das análises granulométricas $(\mathrm{g} / \mathrm{kg})$ do perfil de solo P06.

\begin{tabular}{|c|c|c|c|c|c|c|c|c|c|}
\hline \multirow[b]{2}{*}{$\begin{array}{c}\text { Amostra } \\
\text { P06 }\end{array}$} & \multicolumn{6}{|c|}{ AREIA (Diâmetro em milímetros) } & \multirow[b]{2}{*}{$\begin{array}{c}\text { ARGILA } \\
<0,002 \mathrm{~mm}\end{array}$} & \multirow[b]{2}{*}{$\begin{array}{c}\text { SILTE } \\
0,05-0,002 \mathrm{~mm}\end{array}$} & \multirow[b]{2}{*}{ Artefatos } \\
\hline & $\begin{array}{l}\text { Muito } \\
\text { Grossa } \\
\text { 1,0-2,0 }\end{array}$ & $\begin{array}{l}\text { Grossa } \\
0,5-1,0\end{array}$ & $\begin{array}{c}\text { Média } \\
0,5-0,25\end{array}$ & $\begin{array}{c}\text { Fina } \\
0,25-0,10\end{array}$ & $\begin{array}{c}\text { Muito } \\
\text { Fina } \\
0,10-0,05\end{array}$ & $\begin{array}{l}\text { AREIA } \\
\text { TOTAL }\end{array}$ & & & \\
\hline$A(0-37 \mathrm{~cm})$ & 04 & 50 & 215 & 344 & 174 & 787 & 109 & 104 & 82 \\
\hline $2 A(37-68 \mathrm{~cm})$ & 34 & 121 & 243 & 207 & 122 & 727 & 137 & 136 & 66 \\
\hline $3 A(68-120 \mathrm{~cm})$ & 02 & 17 & 31 & 79 & 171 & 300 & 258 & 442 & 69 \\
\hline
\end{tabular}

Classificação granulométrica americana USDA (1951). 
TABELA 24 - Resultados das análises químicas do perfil de solo P06.

\begin{tabular}{|c|c|c|c|c|}
\hline \multicolumn{2}{|c|}{ Amostra P06 } & $\begin{array}{c}A \\
0-37 \mathrm{~cm}\end{array}$ & $\begin{array}{c}2 A \\
37-68 \mathrm{~cm}\end{array}$ & $\begin{array}{c}3 A \\
68-120 \mathrm{~cm}\end{array}$ \\
\hline \multicolumn{5}{|c|}{ MACRONUTRIENTES } \\
\hline \multirow{3}{*}{$\mathrm{pH}$} & $\mathrm{CaCl}_{2}$ & 6,0 & 6,0 & 5,60 \\
\hline & $\mathrm{H}_{2} \mathrm{O}$ & 6,80 & 6,80 & 6,30 \\
\hline & SMP & 7,20 & 7,15 & 6,85 \\
\hline \multicolumn{2}{|c|}{ Hidrogênio + Alumínio $\mathrm{cmol} / \mathrm{dm}^{3}$} & 1,20 & 1,30 & 1,70 \\
\hline \multicolumn{2}{|c|}{ Alumínio $\mathrm{cmol} / \mathrm{dm}^{3}$} & ALD & ALD & ALD \\
\hline \multicolumn{2}{|c|}{ Cálcio $\mathrm{cmol} / \mathrm{dm}^{3}$} & 2,80 & 3,20 & 4,60 \\
\hline \multicolumn{2}{|c|}{ Magnésio cmol $/ \mathrm{dm}^{3}$} & 0,60 & 0,80 & 1,0 \\
\hline \multicolumn{2}{|c|}{ Potássio $\mathrm{cmol} / \mathrm{dm}^{3}$} & 0,14 & 0,11 & 0,09 \\
\hline \multicolumn{2}{|c|}{ Fósforo (Mehlich) $\mathrm{mg} / \mathrm{dm}^{3}$} & 17,0 & 14,0 & 5,0 \\
\hline \multicolumn{2}{|c|}{ Fósforo (Resina) $\mathrm{mg} / \mathrm{dm}^{3}$} & 23,0 & 19,0 & 8,0 \\
\hline \multicolumn{2}{|c|}{ Carbono $\mathrm{g} / \mathrm{dm}^{3}$} & 10,0 & 8,0 & 7,0 \\
\hline \multicolumn{2}{|c|}{ Matéria Orgânica \% } & 1,70 & 1,40 & 1,20 \\
\hline \multicolumn{2}{|c|}{ Soma de Bases cmol $/ \mathrm{dm}^{3}$} & 3,54 & 4,11 & 5,69 \\
\hline \multicolumn{2}{|c|}{$\mathrm{CTC} \mathrm{cmol} / \mathrm{dm}^{3}$} & 4,74 & 5,41 & 7,39 \\
\hline \multicolumn{2}{|c|}{ Saturação por bases (V) } & 74,68 & 75,97 & 77,0 \\
\hline \multicolumn{2}{|c|}{ Relação Cálcio/Magnésio } & 4,70 & 4,0 & 4,60 \\
\hline \multicolumn{5}{|c|}{ COMPLEXO ADSORVENTE } \\
\hline \multicolumn{2}{|c|}{ Potássio \% da CTC } & 3,0 & 2,0 & 1,20 \\
\hline \multicolumn{2}{|c|}{ Cálcio \% da CTC } & 59,10 & 59,10 & 62,20 \\
\hline \multicolumn{2}{|c|}{ Magnésio \% da CTC } & 12,70 & 14,80 & 13,50 \\
\hline \multicolumn{2}{|c|}{ Hidrogênio \% da CTC } & 25,30 & 24,0 & 23,0 \\
\hline \multicolumn{2}{|c|}{ Alumínio \% da CTC } & 0,0 & 0,0 & 0,0 \\
\hline
\end{tabular}

CTC: Capacidade de Troca Catiônica, ALD: Abaixo do limite detecção

TABELA 25 - Resultados da análise de espectrometria de fluorescência de raios X do perfil de solo P06. Os valores em negrito indicam concentrações acima do VRQ (CETESB 2016) para o elemento analisado, enquanto os valores em vermelho indicam concentrações acima do VP (CETESB 2016).

\begin{tabular}{|c|c|c|c|c|c|}
\hline Amostra P06 & $\begin{array}{c}A \\
0-37 \mathrm{~cm}\end{array}$ & $\begin{array}{c}2 A \\
37-68 \mathrm{~cm}\end{array}$ & $\begin{array}{c}3 A \\
68-120 \mathrm{~cm}\end{array}$ & $V R Q$ & $V P$ \\
\hline \multicolumn{6}{|c|}{$\operatorname{SOMA}(\mu \mathrm{g} / \mathrm{g})$} \\
\hline Bário (Ba) & 397 & 384 & 585 & 75 & 120 \\
\hline Cério (Ce) & 67 & 80 & 111 & - & - \\
\hline Cromo $(\mathrm{Cr})$ & 29,0 & 33 & 27,7 & 40 & 75 \\
\hline Cobre $(\mathrm{Cu})$ & 15,0 & 17,1 & 21,8 & 35 & 60 \\
\hline Gálio/Gases Nobres (Ga) & 11,0 & 11,5 & 21,7 & - & - \\
\hline Lantônio (La) & 42 & 59 & 93 & - & - \\
\hline Nióbio $(\mathrm{Nb})$ & 12,6 & 12,3 & 17,9 & - & - \\
\hline Neodímio (Nd) & 29 & 52 & 62 & - & - \\
\hline Níquel (Ni) & $<2$ & $<2$ & $<2$ & 13 & 30 \\
\hline Chumbo $(\mathrm{Pb})$ & 28,1 & 29,3 & 44 & 17 & 72 \\
\hline Rubídio (Rb) & 119 & 119 & 206 & - & - \\
\hline Escândio (Sc) & 05 & 06 & 11 & - & - \\
\hline Estrôncio (Sr) & 75 & 72 & 108 & - & - \\
\hline Tório (Th) & 32 & 34 & 40 & - & - \\
\hline Vanádio (V) & 63 & 67 & 85 & 275 & 275 \\
\hline Ítrio (Y) & 10,7 & 12,3 & 21,4 & - & - \\
\hline Zinco $(\mathrm{Zn})$ & 99 & 53 & 62 & 60 & 86 \\
\hline Zircônio (Zr) & 301 & 301 & 559 & - & - \\
\hline
\end{tabular}

VRQ: Valor de Referência de Qualidade (CETESB 2016).

VP: Valor de Prevenção (CETESB 2016).

- Elemento não está presente na Lista de Valores orientadores para solo e águas subterrâneas do Estado de São Paulo (CETESB 2016). 
TABELA 26 - Descrição morfológica e particularidades do perfil de solo do ponto P07.

\begin{tabular}{|c|c|c|}
\hline $\begin{array}{c}\text { Coordenadas: } \\
\text { 23K } 0288445 \\
7471255\end{array}$ & Data do campo: $30 / 10 / 15$ & $\begin{array}{l}\text { Classificação do solo (IUSS 2014): } \\
\text { Tecnossolo Úrbico }\end{array}$ \\
\hline
\end{tabular}

Perfil de solo do P07:

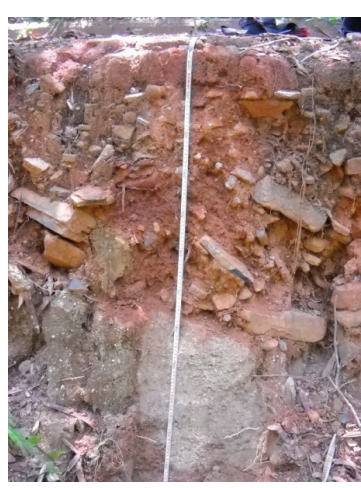

Localização:

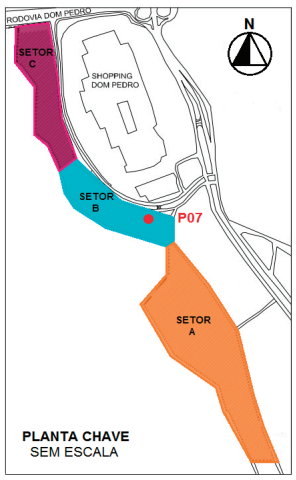

Exemplos de artefatos encontrados:

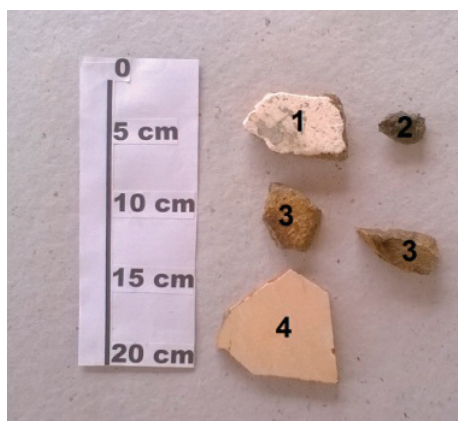

Legenda: 1- Concreto pintado, 2 - Pixe, 3 Concreto, 4 - Revestimento cerâmico.

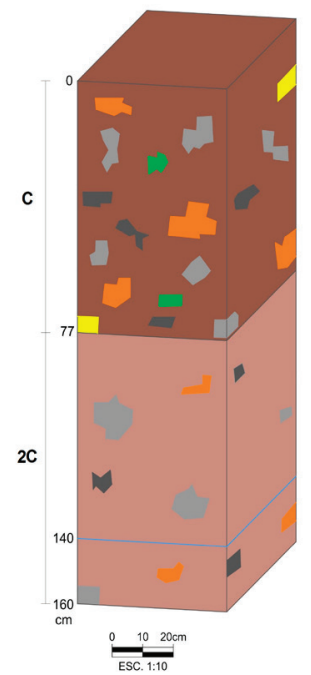

C 0-77 cm; bruno avermelhado (7.5R 4/6); franco argilosa; maciço; duro, firme, plástico, ligeiramente pegajoso; artefatos (blocos de concreto, revestimento cerâmico, pixe, vidro), fragmentos de basalto; transição plana abrupta.

2 C 77-160 cm+; bruno claro (cor 5YR 7/6); franco arenosa; maciça; ligeiramente duro, firme, ligeiramente plástico, não pegajoso; artefatos (concreto, revestimento cerâmico, telhas, vidro), fragmentos de rocha; marca de oscilação do nível d'água na profundidade de $140 \mathrm{~cm}$.

TABELA 27 - Resultados das análises granulométricas $(\mathrm{g} / \mathrm{kg}$ ) do perfil de solo do ponto P07.

\begin{tabular}{|c|c|c|c|c|c|c|c|c|c|}
\hline \multirow[b]{2}{*}{$\begin{array}{c}\text { Amostra } \\
\text { P07 }\end{array}$} & \multicolumn{6}{|c|}{ AREIA (Diâmetro em milimetros) } & \multirow[b]{2}{*}{$\begin{array}{c}\text { ARGILA } \\
<0,002 \mathrm{~mm}\end{array}$} & \multirow[b]{2}{*}{$\begin{array}{c}\text { SILTE } \\
0,05-0,002 \mathrm{~mm}\end{array}$} & \multirow[b]{2}{*}{ Artefatos } \\
\hline & $\begin{array}{l}\text { Muito } \\
\text { Grossa } \\
1,0-2,0\end{array}$ & $\begin{array}{l}\text { Grossa } \\
0,5-1,0\end{array}$ & $\begin{array}{c}\text { Média } \\
0,5-0,25\end{array}$ & $\begin{array}{c}\text { Fina } \\
0,25-0,10\end{array}$ & $\begin{array}{c}\text { Muito } \\
\text { Fina } \\
0,10-0,05\end{array}$ & $\begin{array}{l}\text { AREIA } \\
\text { TOTAL }\end{array}$ & & & \\
\hline$C(0-77 \mathrm{~cm})$ & 64 & 64 & 85 & 78 & 92 & 383 & 244 & 373 & 157 \\
\hline $2 C(77-160 \mathrm{~cm})$ & 64 & 187 & 170 & 128 & 110 & 659 & 111 & 230 & 99 \\
\hline
\end{tabular}

Classificação granulométrica americana USDA (1951). 
TABELA 28 - Resultados das análises químicas do perfil de solo do ponto P07.

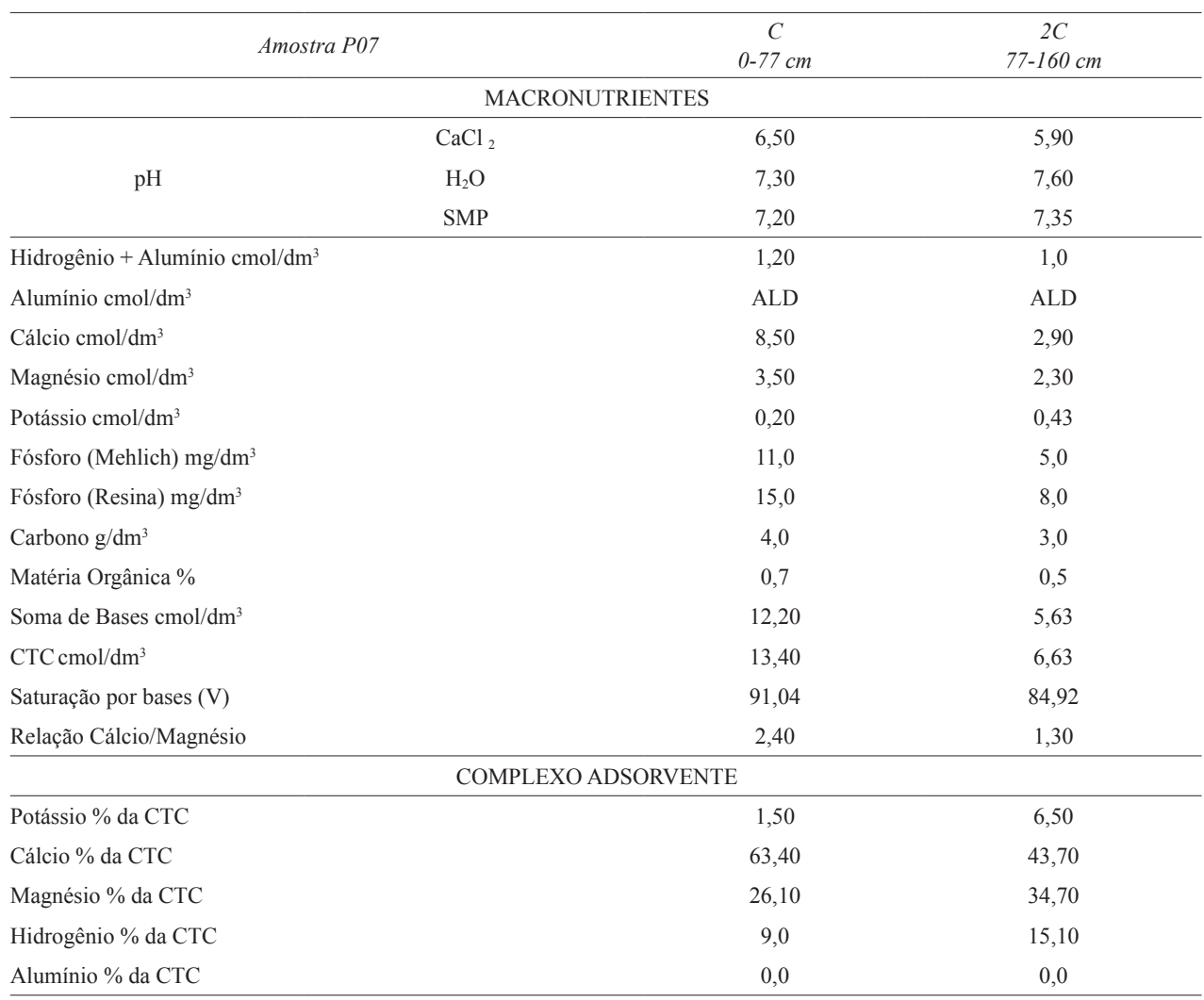

CTC: Capacidade de Troca Catiônica, ALD: Abaixo do limite detecção

TABELA 29 - Resultados da análise de espectrometria de fluorescência de raios X do perfil de solo do ponto P07. Os valores em negrito indicam concentrações acima do VRQ (CETESB 2016) para o elemento analisado, enquanto os valores em vermelho indicam concentrações acima do VP (CETESB 2016).

\begin{tabular}{|c|c|c|c|c|}
\hline Amostra P07 & $\begin{array}{c}C \\
0-77 \mathrm{~cm}\end{array}$ & $\begin{array}{c}2 C \\
77-160 \mathrm{~cm}\end{array}$ & $V R Q$ & $V P$ \\
\hline \multicolumn{5}{|c|}{ SOMA $(\mu \mathrm{g} / \mathrm{g})$} \\
\hline Bário (Ba) & 545 & 1287 & 75 & 120 \\
\hline Cério (Ce) & 37 & 201 & - & - \\
\hline Cromo $(\mathrm{Cr})$ & 103 & 46 & 40 & 75 \\
\hline Cobre $(\mathrm{Cu})$ & 288 & 9,1 & 35 & 60 \\
\hline Gálio/Gases Nobres (Ga) & 20,0 & 19,2 & - & - \\
\hline Lantônio (La) & 50 & 135 & - & - \\
\hline Nióbio (Nb) & 19,3 & 25,4 & - & - \\
\hline Neodímio (Nd) & 52 & 103 & - & - \\
\hline Níquel (Ni) & 35 & $<2$ & 13 & 30 \\
\hline Chumbo $(\mathrm{Pb})$ & 10,0 & 45 & 17 & 72 \\
\hline Rubídio (Rb) & 36 & 254 & - & - \\
\hline Escândio (Sc) & 107 & 07 & - & - \\
\hline Estrôncio (Sr) & 83 & 165 & - & - \\
\hline Tório (Th) & 13,5 & 62 & - & - \\
\hline Vanádio (V) & 519 & 67 & 275 & 275 \\
\hline Ítrio $(\mathrm{Y})$ & 42 & 24,6 & - & - \\
\hline Zinco (Zn) & 105 & 78 & 60 & 86 \\
\hline Zircônio (Zr) & 294 & 486 & - & - \\
\hline
\end{tabular}

VRQ: Valor de Referência de Qualidade (CETESB 2016).

VP: Valor de Prevenção (CETESB 2016).

- Elemento não está presente na Lista de Valores orientadores para solo e águas subterrâneas do Estado de São Paulo (CETESB 2016). 
TABELA 30 - Descrição morfológica e particularidades do perfil de solo do ponto P08.

\begin{tabular}{|c|c|c|}
\hline $\begin{array}{c}\text { Coordenadas: } \\
\text { 23K } 0287988 \\
7471711\end{array}$ & Data do campo: $30 / 10 / 15$ & $\begin{array}{l}\text { Classificação do solo (WRB, 2014): } \\
\text { Tecnossolo Úrbico }\end{array}$ \\
\hline
\end{tabular}
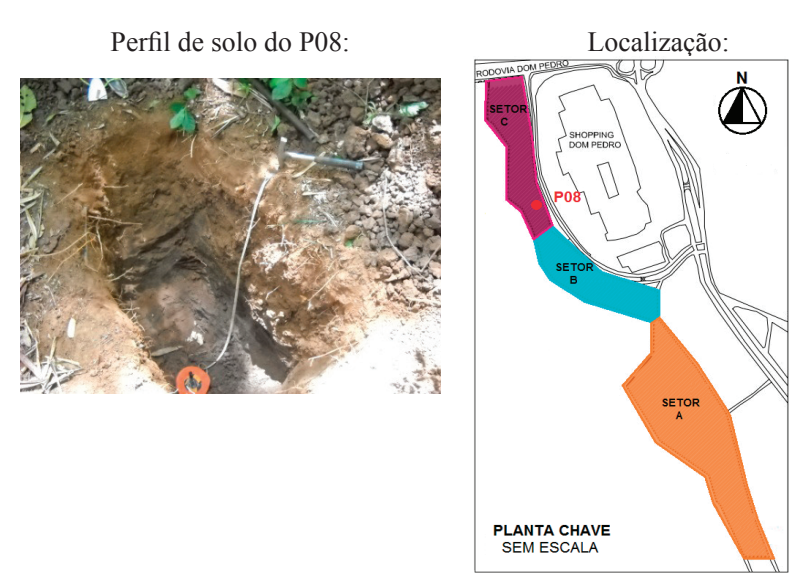

Exemplos de artefatos encontrados:

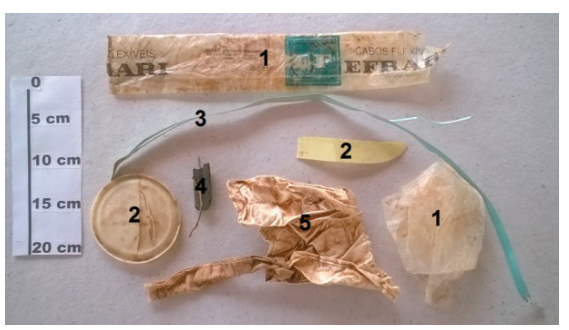

Legenda: 1- Embalagem plástica, 2- Plástico, 3Plástico, 4- Concreto com arame, 5- Lona de PVC.

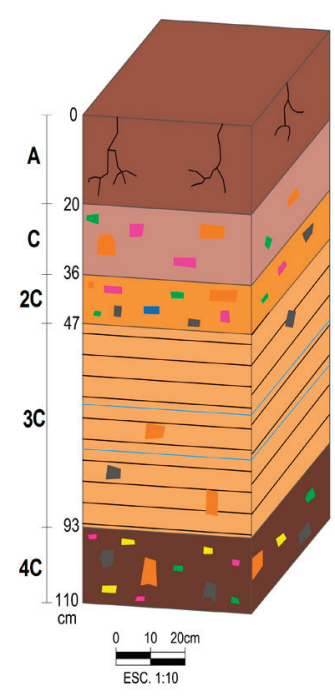

A 0-20 cm; bruno avermelhado (7.5R 3/6); franco arenosa; fraca pequena blocos subangulares; ligeiramente duro, friável, não plástico, não pegajoso; sem artefatos, presença de atividade biológica intensa; transição plana clara.

C 20-36 cm; bruno avermelhado (7.5R 3/6); franco arenosa; maciça; solta, solta, não plástico, ligeiramente pegajoso; artefatos (cimento, tijolos, plástico, telhas); transição plana clara.

$2 C$ 36-47 cm; bruno avermelhado (7.5 R 3/6); argilosa; maciça; duro, firme, plástico, pegajoso; artefatos (concreto, tijolo, plástico, telhas, cerâmica); transição plana gradual.

$3 C$ 47-93 cm; bruno escuro (7.5R 2.5/3); argilosa; estrutura laminar de compactação do solo; muito dura, firme, plástico, pegajoso; artefatos (concreto, telhas, plástico), marcas avermelhadas de oxidação do Ferro (Fe) que podem indicar oscilação do nível d'água; transição plana clara.

4C 93-110 cm+; bruno escuro (7.5YR 3/3); franco argilo arenosa; maciço; muito duro, firme, não plástico, ligeiramente pegajoso; artefatos (concreto, revestimentos cerâmicos, plástico, telhas).

TABELA 31 - Resultados das análises granulométricas ( $\mathrm{g} / \mathrm{kg}$ ) do perfil de solo P08.

\begin{tabular}{|c|c|c|c|c|c|c|c|c|c|}
\hline \multirow[b]{2}{*}{$\begin{array}{c}\text { Amostra } \\
\text { P08 }\end{array}$} & \multicolumn{6}{|c|}{ AREIA (Diâmetro em milimetros) } & \multirow[b]{2}{*}{$\begin{array}{c}\text { ARGILA } \\
<0,002 \mathrm{~mm}\end{array}$} & \multirow[b]{2}{*}{$\begin{array}{c}\text { SILTE } \\
0,05-0,002 \mathrm{~mm}\end{array}$} & \multirow[b]{2}{*}{ Artefatos } \\
\hline & $\begin{array}{l}\text { Muito } \\
\text { Grossa } \\
\text { 1,0-2,0 }\end{array}$ & $\begin{array}{l}\text { Grossa } \\
0,5-1,0\end{array}$ & $\begin{array}{c}\text { Média } \\
0,5-0,25\end{array}$ & $\begin{array}{c}\text { Fina } \\
0,25-0,10\end{array}$ & $\begin{array}{c}\text { Muito } \\
\text { Fina } \\
0,10-0,05\end{array}$ & $\begin{array}{l}\text { AREIA } \\
\text { TOTAL }\end{array}$ & & & \\
\hline$A(0-20 \mathrm{~cm})$ & 02 & 12 & 218 & 321 & 145 & 698 & 195 & 108 & 0 \\
\hline$C(20-36 \mathrm{~cm})$ & 0 & 30 & 357 & 316 & 91 & 794 & 137 & 69 & 98 \\
\hline $2 C(36-47 \mathrm{~cm})$ & 14 & 33 & 82 & 71 & 68 & 268 & 477 & 255 & 102 \\
\hline $3 C(47-93 \mathrm{~cm})$ & 09 & 46 & 121 & 128 & 108 & 412 & 405 & 183 & 57 \\
\hline $4 C(93-110 \mathrm{~cm})$ & 121 & 268 & 141 & 67 & 47 & 644 & 233 & 123 & 111 \\
\hline
\end{tabular}

Classificação granulométrica americana USDA (1951). 
TABELA 32 - Resultados das análises químicas do perfil de solo P08.

\begin{tabular}{|c|c|c|c|c|c|c|}
\hline \multicolumn{2}{|c|}{ Amostra P08 } & $\begin{array}{c}A \\
0-20 \mathrm{~cm}\end{array}$ & $\begin{array}{c}C \\
20-36 \mathrm{~cm}\end{array}$ & $\begin{array}{c}2 C \\
36-47 \mathrm{~cm}\end{array}$ & $\begin{array}{c}3 C \\
47-93 \mathrm{~cm}\end{array}$ & $\begin{array}{c}4 C \\
93-110 \mathrm{~cm}\end{array}$ \\
\hline \multicolumn{7}{|c|}{ MACRONUTRIENTES } \\
\hline \multirow{3}{*}{$\mathrm{pH}$} & $\mathrm{CaCl}_{2}$ & 6,10 & 6,10 & 5,70 & 6,00 & 6,10 \\
\hline & $\mathrm{H}_{2} \mathrm{O}$ & 6,80 & 6,90 & 6,50 & 6,80 & 6,90 \\
\hline & SMP & 7,15 & 7,30 & 7,00 & 7,05 & 7,20 \\
\hline \multicolumn{2}{|c|}{ Hidrogênio + Alumínio $\mathrm{cmol} / \mathrm{dm}^{3}$} & 1,30 & 1,10 & 1,50 & 1,40 & 1,20 \\
\hline \multicolumn{2}{|c|}{ Alumínio $\mathrm{cmol} / \mathrm{dm}^{3}$} & ALD & ALD & ALD & ALD & ALD \\
\hline \multicolumn{2}{|c|}{ Cálcio $\mathrm{cmol} / \mathrm{dm}^{3}$} & 3,70 & 2,0 & 3,90 & 5,0 & 3,80 \\
\hline \multicolumn{2}{|c|}{ Magnésio $\mathrm{cmol} / \mathrm{dm}^{3}$} & 0,80 & 0,60 & 1,00 & 1,10 & 1,00 \\
\hline \multicolumn{2}{|c|}{ Potássio $\mathrm{cmol} / \mathrm{dm}^{3}$} & 0,42 & 0,31 & 0,30 & 0,27 & 0,25 \\
\hline \multicolumn{2}{|c|}{ Fósforo (Mehlich) $\mathrm{mg} / \mathrm{dm}^{3}$} & 26,0 & 22,0 & 17,0 & 5,0 & 6,0 \\
\hline \multicolumn{2}{|c|}{ Fósforo (Resina) $\mathrm{mg} / \mathrm{dm}^{3}$} & 39,0 & 31,0 & 24,0 & 8,0 & 9,0 \\
\hline \multicolumn{2}{|c|}{ Carbono $\mathrm{g} / \mathrm{dm}^{3}$} & 15,0 & 10,0 & 8,0 & 6,0 & 3,0 \\
\hline \multicolumn{2}{|c|}{ Matéria Orgânica \% } & 2,60 & 1,70 & 1,40 & 1,00 & 0,50 \\
\hline \multicolumn{2}{|c|}{ Soma de Bases $\mathrm{cmol} / \mathrm{dm}^{3}$} & 4,92 & 2,91 & 5,20 & 6,37 & 5,05 \\
\hline \multicolumn{2}{|c|}{$\mathrm{CTC} \mathrm{cmol} / \mathrm{dm}^{3}$} & 6,22 & 4,01 & 6,70 & 7,77 & 6,25 \\
\hline \multicolumn{2}{|c|}{ Saturação por bases (V) } & 79,10 & 72,57 & 77,61 & 81,98 & 80,80 \\
\hline \multicolumn{2}{|c|}{ Relação Cálcio/Magnésio } & 4,60 & 3,30 & 3,90 & 4,50 & 3,80 \\
\hline \multicolumn{7}{|c|}{ COMPLEXO ADSORVENTE } \\
\hline \multicolumn{2}{|c|}{ Potássio \% da CTC } & 6,80 & 7,70 & 4,50 & 3,50 & 4,0 \\
\hline \multicolumn{2}{|c|}{ Cálcio \% da CTC } & 59,50 & 49,90 & 58,20 & 64,40 & 60,80 \\
\hline \multicolumn{2}{|c|}{ Magnésio \% da CTC } & 12,90 & 15,00 & 14,90 & 14,20 & 16,0 \\
\hline \multicolumn{2}{|c|}{ Hidrogênio \% da CTC } & 20,90 & 27,40 & 22,40 & 18,00 & 19,20 \\
\hline \multicolumn{2}{|c|}{ Alumínio \% da CTC } & 0,0 & 0,0 & 0,0 & 0,0 & 0,0 \\
\hline
\end{tabular}

CTC: Capacidade de Troca Catiônica, ALD: Abaixo do limite detecção

TABELA 33 - Resultados da análise de espectrometria de fluorescência de raios X do perfil de solo P08. Os valores em negrito indicam concentrações acima do VRQ (CETESB 2016) para o elemento analisado, enquanto os valores em vermelho indicam concentrações acima do VP (CETESB 2016).

\begin{tabular}{|c|c|c|c|c|c|c|c|}
\hline Amostra P08 & $\begin{array}{c}A \\
0-20 \mathrm{~cm}\end{array}$ & $\begin{array}{c}C \\
20-36 \mathrm{~cm}\end{array}$ & $\begin{array}{c}2 C \\
36-47 \mathrm{~cm}\end{array}$ & $\begin{array}{c}3 C \\
47-93 \mathrm{~cm}\end{array}$ & $\begin{array}{c}4 C \\
93-110 \mathrm{~cm}\end{array}$ & $V R Q$ & $V P$ \\
\hline \multicolumn{8}{|c|}{$\operatorname{SOMA}(\mu \mathrm{g} / \mathrm{g})$} \\
\hline Bário (Ba) & 392 & 371 & 457 & 476 & 368 & 75 & 120 \\
\hline Cério (Ce) & 84 & 67 & 82 & 76 & 51 & - & - \\
\hline Cromo $(\mathrm{Cr})$ & 31 & 42 & 39 & 34 & 43 & 40 & 75 \\
\hline Cobre $(\mathrm{Cu})$ & 37 & 32 & 47 & 20,3 & 10,4 & 35 & 60 \\
\hline Gálio/Gases Nobres (Ga) & 12,6 & 11,1 & 21,9 & 23,2 & 13,8 & - & - \\
\hline Lantônio (La) & 56 & 42 & 75 & 79 & 44 & - & - \\
\hline Nióbio (Nb) & 15,4 & 13,8 & 18,1 & 13,1 & 9,6 & - & - \\
\hline Neodímio (Nd) & 31 & 31 & 62 & 55 & 30 & - & - \\
\hline Níquel (Ni) & $<2$ & $<2$ & $<2$ & $<2$ & $<2$ & 13 & 30 \\
\hline Chumbo $(\mathrm{Pb})$ & 34 & 28,6 & 47 & 31 & 22,8 & 17 & 72 \\
\hline Rubídio (Rb) & 91 & 86 & 118 & 121 & 88 & - & - \\
\hline Escândio (Sc) & 11 & 10 & 21 & 14 & 06 & - & - \\
\hline Estrôncio (Sr) & 71 & 68 & 67 & 73 & 61 & - & - \\
\hline Tório (Th) & 31 & 26,6 & 32 & 32 & 20,9 & - & - \\
\hline Vanádio (V) & 133 & 113 & 186 & 86 & 46 & 275 & 275 \\
\hline Ítrio $(Y)$ & 13,7 & 10,5 & 20,7 & 18,0 & 11,4 & - & - \\
\hline Zinco (Zn) & 59 & 51 & 71 & 38 & 24,2 & 60 & 86 \\
\hline Zircônio (Zr) & 354 & 266 & 312 & 256 & 158 & - & - \\
\hline
\end{tabular}

VRQ: Valor de Referência de Qualidade (CETESB 2016).

VP: Valor de Prevenção (CETESB 2016).

- Elemento não está presente na Lista de Valores orientadores para solo e águas subterrâneas do Estado de São Paulo (CETESB 2016). 
TABELA 34 - Descrição morfológica e particularidades do perfil de solo do ponto P09.

\begin{tabular}{|c|c|c|}
\hline $\begin{array}{c}\text { Coordenadas: } \\
\text { 23K } 0287914 \\
7472002\end{array}$ & Data do campo: $30 / 10 / 15$ & $\begin{array}{l}\text { Classificação do solo (IUSS 2014): } \\
\text { Tecnossolo Úrbico }\end{array}$ \\
\hline
\end{tabular}

Perfil de solo do P09:

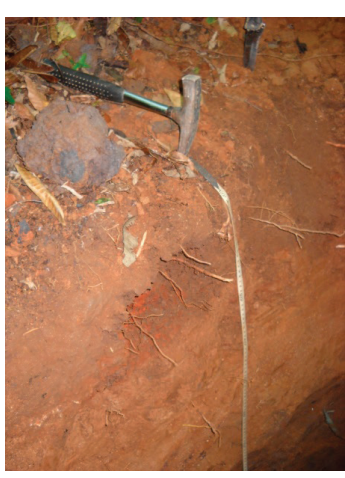

Localização:

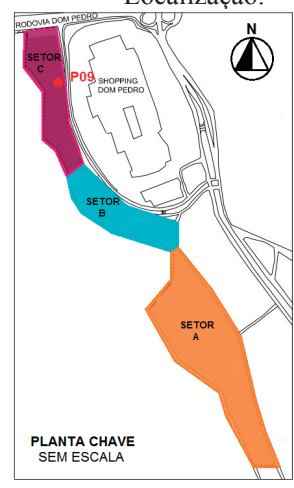

Exemplos de artefatos encontrados:

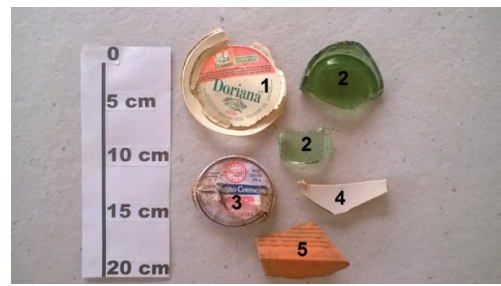

Legenda: 1- Embalagem plástica, 2- Vidro, 3Alumínio, 4- Revestimento cerâmico, 5- Tijolo.

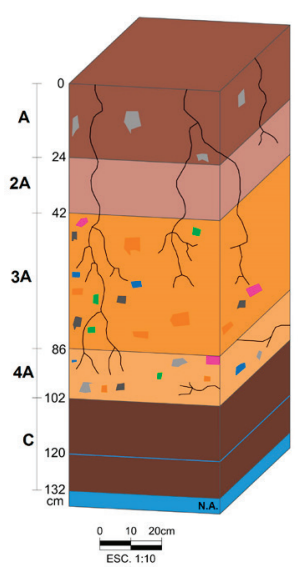

A 0-24 cm; bruno avermelhado (5R 3/8); franco argilosa; fraca pequena blocos subangulares; duro, firme, plástico, pegajoso; sem artefatos, fragmentos de rocha, atividade biológica intensa; transição plana clara.

2 A 24-42 cm; bruno avermelhado (7.5R 4/6); franco argilo siltosa; maciço; muito duro, firme, plástico, pegajoso; sem artefatos, presença de mica (mineral facilmente intemperizável), atividade biológica; transição plana clara.

$3 A$ 42-86 cm; bruno (7.5 R 3/4); franco argilo arenosa; maciça; duro, firme, plástico, pegajoso; artefatos (concreto, tijolo, plástico, telhas, cerâmica), presença de atividade biológica; transição plana abrupta.

4A 86-102 cm; bruno (10R 4/4); franco argilo arenosa; maciço; duro, firme, não plástico, ligeiramente pegajoso; fragmentos de rocha (alterita), artefatos (concreto, tijolos, borracha e plástico), atividade biológica; transição plana gradual.

C 102-132 cm+; bruno escuro (7.5YR 3/2); franco arenosa; maciça; macio, friável, não plástico, não pegajoso; sem artefatos, marca de oscilação do nível água na profundidade de $120 \mathrm{~cm}$.

TABELA 35 - Resultados das análises granulométricas ( $\mathrm{g} / \mathrm{kg}$ ) do perfil de solo do ponto P09.

\begin{tabular}{|c|c|c|c|c|c|c|c|c|c|}
\hline \multirow[b]{2}{*}{$\begin{array}{c}\text { Amostra } \\
\text { P09 }\end{array}$} & \multicolumn{6}{|c|}{ AREIA (Diâmetro em milímetros) } & \multirow[b]{2}{*}{$\begin{array}{c}\text { ARGILA } \\
<0,002 \mathrm{~mm}\end{array}$} & \multirow[b]{2}{*}{$\begin{array}{c}\text { SILTE } \\
0,05-0,002 \mathrm{~mm}\end{array}$} & \multirow[b]{2}{*}{ Artefatos } \\
\hline & $\begin{array}{l}\text { Muito } \\
\text { Grossa } \\
1,0-2,0\end{array}$ & $\begin{array}{l}\text { Grossa } \\
0,5-1,0\end{array}$ & $\begin{array}{c}\text { Média } \\
0,5-0,25\end{array}$ & $\begin{array}{c}\text { Fina } \\
0,25-0,10\end{array}$ & $\begin{array}{c}\text { Muito } \\
\text { Fina } \\
0,10-0,05\end{array}$ & $\begin{array}{l}\text { AREIA } \\
\text { TOTAL }\end{array}$ & & & \\
\hline$A(0-24 \mathrm{~cm})$ & 0 & 13 & 50 & 148 & 184 & 395 & 336 & 270 & 0 \\
\hline $2 A(24-42 \mathrm{~cm})$ & 0 & 0 & 0 & 11 & 90 & 101 & 376 & 523 & 0 \\
\hline $3 A(42-86 \mathrm{~cm})$ & 04 & 18 & 94 & 178 & 159 & 453 & 288 & 259 & 77 \\
\hline $4 A(86-102 \mathrm{~cm})$ & 16 & 41 & 104 & 162 & 139 & 462 & 297 & 241 & 61 \\
\hline$C(102-132 \mathrm{~cm})$ & 20 & 150 & 317 & 176 & 81 & 744 & 143 & 113 & 0 \\
\hline
\end{tabular}

Classificação granulométrica americana USDA (1951). 
TABELA 36 - Resultados das análises químicas do perfil de solo do ponto P09.

\begin{tabular}{|c|c|c|c|c|c|c|}
\hline \multicolumn{2}{|c|}{ Amostra P09 } & $\begin{array}{c}A \\
0-24 \mathrm{~cm}\end{array}$ & $\begin{array}{c}2 A \\
24-42 \mathrm{~cm}\end{array}$ & $\begin{array}{c}3 A \\
42-86 \mathrm{~cm}\end{array}$ & $\begin{array}{c}4 A \\
86-102 \mathrm{~cm}\end{array}$ & $\begin{array}{c}C \\
102-132 \mathrm{~cm}\end{array}$ \\
\hline \multicolumn{7}{|c|}{ MACRONUTRIENTES } \\
\hline \multirow{3}{*}{$\mathrm{pH}$} & $\mathrm{CaCl}_{2}$ & 5,2 & 5,3 & 5,0 & 4,9 & 4,7 \\
\hline & $\mathrm{H}_{2} \mathrm{O}$ & 5,9 & 6,0 & 5,7 & 5,7 & 5,5 \\
\hline & SMP & 6,55 & 6,65 & 6,35 & 6,70 & 6,65 \\
\hline \multicolumn{2}{|c|}{ Hidrogênio + Alumínio $\mathrm{cmol} / \mathrm{dm}^{3}$} & 2,4 & 2,1 & 2,9 & 2,0 & 2,1 \\
\hline \multicolumn{2}{|c|}{ Alumínio $\mathrm{cmol} / \mathrm{dm}^{3}$} & ALD & ALD & ALD & ALD & ALD \\
\hline \multicolumn{2}{|c|}{ Cálcio $\mathrm{cmol} / \mathrm{dm}^{3}$} & 4,6 & 4,7 & 3,4 & 3,5 & 1,8 \\
\hline \multicolumn{2}{|c|}{ Magnésio cmol/ $\mathrm{dm}^{3}$} & 1,2 & 1,5 & 1,2 & 1,1 & 0,8 \\
\hline \multicolumn{2}{|c|}{ Potássio cmol $/ \mathrm{dm}^{3}$} & 0,34 & 0,23 & 0,10 & 0,21 & 0,13 \\
\hline \multicolumn{2}{|c|}{ Fósforo (Mehlich) $\mathrm{mg} / \mathrm{dm}^{3}$} & 9,0 & 5,0 & 7,0 & 4,0 & 5,0 \\
\hline \multicolumn{2}{|c|}{ Fósforo (Resina) $\mathrm{mg} / \mathrm{dm}^{3}$} & 15,0 & 8,0 & 12,0 & 7,0 & 8,0 \\
\hline \multicolumn{2}{|c|}{ Carbono $\mathrm{g} / \mathrm{dm}^{3}$} & 13,0 & 10,0 & 6,0 & 4,0 & 3,0 \\
\hline \multicolumn{2}{|c|}{ Matéria Orgânica \% } & 2,2 & 1,7 & 1,0 & 0,7 & 0,5 \\
\hline \multicolumn{2}{|c|}{ Soma de Bases $\mathrm{cmol} / \mathrm{dm}^{3}$} & 6,14 & 6,43 & 4,70 & 4,81 & 2,73 \\
\hline \multicolumn{2}{|c|}{$\mathrm{CTC} \mathrm{cmol} / \mathrm{dm}^{3}$} & 8,54 & 8,53 & 7,60 & 6,81 & 4,83 \\
\hline \multicolumn{2}{|c|}{ Saturação por bases (V) } & 71,90 & 75,38 & 61,84 & 70,63 & 56,52 \\
\hline \multicolumn{2}{|c|}{ Relação Cálcio/Magnésio } & 3,8 & 3,7 & 2,8 & 3,2 & 2,3 \\
\hline \multicolumn{7}{|c|}{ COMPLEXO ADSORVENTE } \\
\hline \multicolumn{2}{|c|}{ Potássio \% da CTC } & 4,0 & 2,7 & 1,3 & 3,1 & 2,7 \\
\hline \multicolumn{2}{|c|}{ Cálcio \% da CTC } & 53,9 & 55,1 & 44,7 & 51,4 & 37,3 \\
\hline \multicolumn{2}{|c|}{ Magnésio \% da CTC } & 14,1 & 17,6 & 15,8 & 16,2 & 16,6 \\
\hline \multicolumn{2}{|c|}{ Hidrogênio \% da CTC } & 28,1 & 24,6 & 38,2 & 29,4 & 43,5 \\
\hline \multicolumn{2}{|c|}{ Alumínio \% da CTC } & 0,0 & 0,0 & 0,0 & 0,0 & 0,0 \\
\hline
\end{tabular}

CTC: Capacidade de Troca Catiônica, ALD: Abaixo do limite detecção

TABELA 37 - Resultados da análise de espectrometria de fluorescência de raios X do perfil de solo do ponto P09. Os valores em negrito indicam concentrações acima do VRQ (CETESB 2016) para o elemento analisado, enquanto os valores em vermelho indicam concentrações acima do VP (CETESB 2016).

\begin{tabular}{|c|c|c|c|c|c|c|c|}
\hline Amostra P09 & $\begin{array}{c}A \\
0-24 \mathrm{~cm}\end{array}$ & $\begin{array}{c}2 A \\
24-42 \mathrm{~cm} \\
\end{array}$ & $\begin{array}{c}3 A \\
42-86 \mathrm{~cm}\end{array}$ & $\begin{array}{c}4 A \\
86-102 \mathrm{~cm} \\
\end{array}$ & $\begin{array}{c}C \\
102-132 \mathrm{~cm} \\
\end{array}$ & $V R Q$ & $V P$ \\
\hline \multicolumn{8}{|c|}{ SOMA $(\mu g / g)$} \\
\hline Bário (Ba) & 366 & 532 & 468 & 503 & 440 & 75 & 120 \\
\hline Cério (Ce) & 74 & 72 & 102 & 86 & 77 & - & - \\
\hline Cromo $(\mathrm{Cr})$ & 63 & 52 & 32 & 35 & 41 & 40 & 75 \\
\hline Cobre $(\mathrm{Cu})$ & 104 & 76 & 39 & 46 & 6,8 & 35 & 60 \\
\hline Gálio/Gases Nobres (Ga) & 19,7 & 27,0 & 17,7 & 22,0 & 10,4 & - & - \\
\hline Lantônio (La) & 75 & 105 & 93 & 107 & 48 & - & - \\
\hline Nióbio (Nb) & 19,2 & 19,5 & 17,7 & 16,7 & 9,4 & - & - \\
\hline Neodímio (Nd) & 58 & 67 & 57 & 63 & 28 & - & - \\
\hline Níquel (Ni) & $<2$ & $<2$ & $<2$ & $<2$ & $<2$ & 13 & 30 \\
\hline Chumbo $(\mathrm{Pb})$ & 33 & 33 & 44 & 36 & 26,7 & 17 & 72 \\
\hline Rubídio (Rb) & 93 & 186 & 115 & 142 & 99 & - & - \\
\hline Escândio (Sc) & 31 & 30 & 11 & 16 & 05 & - & - \\
\hline Estrôncio (Sr) & 72 & 67 & 82 & 77 & 77 & - & - \\
\hline Tório (Th) & 35 & 25,2 & 48 & 33 & 25,6 & - & - \\
\hline Vanádio (V) & 319 & 227 & 138 & 155 & 36 & 275 & 275 \\
\hline Ítrio (Y) & 21,4 & 37 & 20,5 & 27,9 & 10,2 & - & - \\
\hline Zinco (Zn) & 213 & 101 & 60 & 70 & 18 & 60 & 86 \\
\hline Zircônio (Zr) & 508 & 293 & 526 & 329 & 205 & - & - \\
\hline
\end{tabular}

VRQ: Valor de Referência de Qualidade (CETESB 2016).

VP: Valor de Prevenção (CETESB 2016).

- Elemento não está presente na Lista de Valores orientadores para solo e águas subterrâneas do Estado de São Paulo (CETESB 2016). 


\section{DISCUSSÃO DOS RESULTADOS}

5.1 Gênese dos Tecnossolos no Parque Linear Ribeirão das Pedras e o histórico de uso e ocupação local

O conceito central dos Tecnossolos é o domínio da atividade humana sobre as propriedades e funções do solo. O histórico de uso e ocupação do Parque Linear Ribeirão das Pedras, no setor entre sua nascente e a Rodovia Dom Pedro I/SP-65 mostra que as intervenções antrópicas na região são anteriores a 1969.

É difícil precisar a data em que a cobertura vegetal original da região foi suprimida, pode-se supor que isso tenha ocorrido na segunda metade do século XVIII (1750-1800), com a chegada de fazendeiros vindos de outras regiões da Capitania de São Paulo em busca de terras para o cultivo de cana-de-açúcar e mais tarde café (PREFEITURA DE CAMPINAS, acesso em 05/07/17).

Em 1970 o uso do solo nas margens do ribeirão era rural, seja para cultivo ou pastagem, sujeito às intervenções antrópicas pertinentes a essas atividades (compactação pela passagem do gado, fertilizantes, agrotóxicos, insumos, aragem, etc.).

A partir de 1995, o uso urbano passou a predominar na sub-bacia, com um notável adensamento das construções e ruas pavimentadas. Estima-se que nessa época tenha começado o descarte ilegal de resíduos da construção civil e lixo doméstico no local, além da canalização da nascente. O ponto P09, no Setor C do Parque Linear, pode ajudar a confirmar essa estimativa, seu horizonte $3 \mathrm{~A}$ (42-86 $\mathrm{cm}$ de profundidade) continha parte de uma embalagem plástica (tampa) de margarina preservada, da marca Doriana, produto fabricado em 1996.

Apesar da criação do Parque Linear Ribeirão das Pedras em 1999 e do desenvolvimento da vegetação, o descarte ilegal de resíduos sólidos continuou, bem como a deposição de camadas de solo provenientes de outros locais. No horizonte $2 \mathrm{C}$ (47-66 $\mathrm{cm}$ de profundidade) do ponto P05 foi coletada parte de uma embalagem de barra de cereais da marca Baldaracci fabricada em 2012.

\subsection{Caracterização dos perfis de solo}

A caracterização das amostras de solo dos perfis estudados permite classificar os Tecnossolos encontrados como Úrbicos. O qualificador Urbic significa entulho e descarte de assentamentos humanos (SCHAD 2018). São solos caracterizados por conter:

- Camada maior ou igual a $20 \mathrm{~cm}$ de espessura dentro dos primeiros $100 \mathrm{~cm}$ a partir da superfície do solo contendo $20 \%$ de artefatos antrópicos por volume (IUSS 2014);

- Os artefatos podem estar distribuídos por todo o perfil;

- Artefatos: fragmentos de objetos manufaturados (tijolo, vidro, concreto, cinzas, asfalto, madeira, plástico, ligas metálicas) (FANNING \& FANNING 1989);

- Apresentam grande variabilidade vertical e horizontal o que significa diferentes graus de transformações morfológicas (IUSS 2014).

Segundo a WRB (IUSS 2014), esses solos podem ser parcialmente tecnogênicos, ou seja, as transformações estão restritas aos horizontes mais superficiais, enquanto os horizontes mais profundos são naturais ou modificados por atividades agropecuárias. É o que pôde ser observado nos pontos P02, P03, P04, no Setor A, e no P09, no Setor $\mathrm{C}$, onde os horizontes mais profundos conservaram algumas características encontradas nos solos naturais de várzeas, como mosqueamento, e não foram encontrados artefatos.

Os pontos P01, P05, P06 no Setor A do Parque, P07 no Setor B, e o P08 no Setor C são Tecnossolos Úrbicos típicos, pois apresentaram artefatos distribuídos por todo o perfil.

Os Tecnossolos Úrbicos do Parque Linear Ribeirão das Pedras são, em sua maioria, arenosos, o que pode estar relacionado tanto com a sua localização nas proximidades do leito do ribeirão quanto o tipo de material aí descartado.

\subsection{Fertilidade dos solos e artefatos antrópicos}

Apesar da pouca manutenção e do contínuo descarte ilegal de resíduos sólidos, a vegetação arbórea do Parque Linear Ribeirão das Pedras está se desenvolvendo, podendo ser classificada como secundária em estado inicial de regeneração. Deve-se lembrar, também, que na margem esquerda do Ribeirão das Pedras, nos Setores $\mathrm{B}$ e C, existem áreas destinadas ao cultivo de hortaliças.

De acordo com os resultados obtidos com as análises químicas de macronutrientes e complexo adsorvente, os Tecnossolos Úrbicos do Parque Linear ribeirão das Pedras são, em geral, 
quimicamente férteis para as condições em que se encontram.

Todos os pontos amostrados, com exceção do P07, no Setor B, apresentaram atividade biológica, seja pela presença de organismos do solo (como minhocas) nos horizontes mais superficiais, seja pela presença de raízes de diferentes proporções nos horizontes superficiais e até nos mais profundos.

As concentrações de Cálcio $(\mathrm{Ca})$, Fósforo $(\mathrm{P})$, Potássio $(\mathrm{K})$ e Magnésio $(\mathrm{Mg})$, macronutrientes essenciais para o desenvolvimento dos vegetais, são relativamente altas em todos os pontos amostrados. Naturalmente, solos tropicais em condições similares apresentam níveis baixos de Cálcio e Magnésio (IAC 1997).

A saturação por bases e as concentrações de matéria orgânicas também apresentaram valores acima dos esperados para os solos da região. Mesmo nos pontos P02 e P04, no Setor A, P08 e $\mathrm{P} 09$, no Setor C, que apresentaram valores de $\mathrm{pH}$ mais ácidos, foi possível verificar o desenvolvimento do sistema radicular das plantas.

Essas características podem estar relacionadas principalmente pela decomposição dos resíduos da construção civil, uma vez que muitos desses materiais como o cimento, argamassas, tijolos, etc. têm carbonato de cálcio, sulfato de cálcio, magnésio e outros elementos em sua constituição. Além disso, há também a decomposição da matéria orgânica proveniente da camada de serapilheira.

\subsection{Metais no solo e artefatos antrópicos}

A composição dos solos é extremamente diversa e controlada por muitos fatores, sendo os principais as condições climáticas e o material parental.

Para SINGH \& STEINNES (1994) os metais nos solos são derivados tanto do intemperismo que age sobre o material parental, como de fontes externas naturais (erupção vulcânica) ou antrópicas (indústria, agricultura, urbanização).

Os resultados das análises de espectrometria de fluorescência de raios X mostraram concentrações acima dos Valores de Prevenção para alguns elementos quando comparados aos valores da Lista de Valores Orientadores para Solo e Água Subterrânea no Estado de São Paulo (CETESB 2016):

- Bário $(\mathrm{Ba})$ : todos os pontos apresentaram concentrações superiores do que o estabelecido nos Valores de Prevenção (VP);
- Cobre (Cu): os pontos P04 - Setor A, P07 - Setor B e P09 - Setor C apresentaram concentrações superiores do que o estabelecido nos Valores de Prevenção (VP);

- Cromo (Cr): o ponto P07 - Setor B apresentou concentração superior do que o estabelecido nos Valores de Prevenção (VP);

- Níquel (Ni): o ponto P07 - Setor B apresentou concentração superior do que o estabelecido nos Valores de Prevenção (VP);

-Vanádio (V): os pontos P04 - Setor A, P07 - Setor B e P09 - Setor C apresentaram concentrações superiores do que o estabelecido nos Valores de Prevenção (VP);

- Zinco (Zn): os pontos P06 - Setor A, P07 - Setor B e P09 - Setor C apresentaram concentrações superiores do que o estabelecido nos Valores de Prevenção (VP).

Os elementos mencionados podem estar presentes nos artefatos encontrados durante a escavação e descrição dos perfis de solo, sendo que provavelmente a decomposição desses materiais acabou por transportá-los para o solo. O chumbo, zinco, bário e vanádio podem estar associados a fragmentos de materiais cerâmicos; materiais plásticos podem conter chumbo e níquel, enquanto fragmentos de borracha, chumbo e zinco.

É importante ressaltar que nenhum dos elementos analisados ultrapassou os Valores de Intervenção (VI) para uso residencial do solo, estabelecidos pela CETESB (2016). Entretanto os pontos P04, P05 e P06 (Setor A), P07 (Setor B) e P09 (Setor C) apresentaram horizontes com concentrações de Bário acima do valor de intervenção (VI) estabelecido para o uso agrícola. Na margem esquerda do ribeirão das Pedras, nos setores $\mathrm{B}$ e C, existem propriedades produtoras de hortaliças. É possível que os vegetais produzidos na área possam ser contaminados com este elemento, entretanto novos estudos seriam necessários.

O bário é um elemento químico pertencente à classe dos metais alcalinos terrosos, considerado tóxico, de coloração prateada, com alto ponto de fusão, facilmente oxidável pelo ar, não sendo encontrado livre na natureza, devido a sua elevada reatividade (REMIÃO 2012/2013). À temperatura ambiente encontra-se no estado sólido. A toxicidade humana do bário ocorre principalmente devido à ingestão acidental de derivados solúveis em meio aquoso ou ácido. Outras vias de intoxicação são a absorção através de queimaduras químicas ou inalação de vapores (REMIÃO 2012/2013). 
Todos os compostos de bário, que são solúveis em água ou em ácido, são venenosos. $\mathrm{O}$ excesso de bário no organismo pode causar sintomas gastrointestinais, cardiovasculares, respiratórios e neuromusculares (REMIÃO 2012/2013), como: náuseas, vômitos, diarreia, dor abdominal, tremores, fibrilação muscular, crises convulsivas e até coma.

\section{CONCLUSÕES}

A influência antrópica nos solos do Parque Linear ribeirão das Pedras no município de Campinas é evidente, caracterizando-se, de um lado, por perfis que foram soterrados por aterros (depósitos tecnogênicos) e depois desenvolveram limitada pedogênese e, por outro, perfis onde foram incorporados artefatos de diferentes características em diferentes profundidades. A ação humana nestes perfis, especialmente caracterizados por resíduos da construção civil e resíduos domésticos, permite classificar os perfis como Tecnossolos Úrbicos.

Das características descritas para estes solos, a que suscita maior preocupação é a presença de valores relativamente elevados de diferentes metais, destacando-se o bário, que apareceu em concentrações superiores ao estabelecido nos Valores de Prevenção (VP) em todos os pontos estudados e acima do Valor de Intervenção (VI) para uso agrícola nos pontos $\mathrm{P} 04, \mathrm{P} 05, \mathrm{P} 06, \mathrm{P} 07$ e P09. A decomposição dos artefatos antrópicos, especialmente restos de construção civil, pode ter favorecido ainda o aumento da fertilidade do solo.

\section{AGRADECIMENTOS}

Aos amigos Estéfano Seneme Gobbi, Marcelo da Silva Gigliotti e André Luiz de Souza Celarino pelo apoio nos trabalhos de campo. O Segundo autor agradece à Bolsa Produtividade em Pesquisa CNPq (Processo 307951/2018-9).Ao professor e pesquisador Alex Ubiratan Goossens Peloggia pelo convite para essa publicação. Aos editores e relatores da Revista do IG pelas sugestões apresentadas.

\section{REFERÊNCIAS BIBLIOGRÁFICAS}

CAMARGO, O.A.; MONIZ, A.C.; JORGE, J.A.; VALADARES, J.M.A.S. 2009. Métodos de Análise Química, Mineralógica e Física de
Solos do Instituto Agronômico de Campinas. Campinas, Instituto Agronômico, 77 p. (Boletim Técnico, 106, Edição revista e atualizada).

CAMPINAS. 2013. Plano municipal de saneamento básico Campinas/SP - Produto 1 Diagnóstico, Caracterização e Análise Crítica. Secretaria Municipal do Verde e Desenvolvimento Sustentável, Campinas, Anexo 3 - Geomorfologia e Relevo. 291 p.

CEPAGRI - CENTRO DE PESQUISAS METEOROLÓGICAS E CLIMÁTICAS APLICADAS À AGRICULTURA. 2016. Climatologia Campinas. Disponível em https://www.cpa.unicamp.br/graficos. Acessado em 21 dez. 2016.

CHARZYNSKI, P.; HULISZ, P.; BEDNAREK, R. 2013. Technogenic Soils of Poland. Polish Society of Soil Science, Torún, 358 p.

CHEMEKOV, Y.F. 1983. Technogenic deposits. In: INQUA, INQUA CONGRESS, 11, Moscow, Abstracts, v.3, p. 62.

CHRISTOFOLETTI, A.; FEDERICI, H. 1972. A Terra Campineira: análise do quadro natural. Indústrias Gráficas Mousinho, Campinas, $100 \mathrm{p}$.

COELHO, R.M.; VALLADARES, G.S.; CHIBA, M.K. 2008. Mapa pedológico semidetalhado do município de Campinas, SP. Escala 1:50.000. Embrapa, Campinas.

CETESB - COMPANHIA AMBIENTAL DO ESTADO DE SÃO PAULO. 2001. Relatório de estabelecimento de valores orientadores para solos e águas subterrâneas no Estado de São Paulo. CETESB, São Paulo, 73 p. (Série Relatórios Ambientais)

CETESB - COMPANHIA AMBIENTAL DO ESTADO DE SÃO PAULO. 2016. Decisão de Diretoria $n^{\circ}$ 256/2016/E de 22 de novembro de 2016. Dispõe sobre a aprovação dos "Valores orientadores para Solo e Águas Subterrâneas no Estado de São Paulo" - 2016 e outras providências.

CRAUL, P.J. 1985. A description of urban soils and their desired characteristics. Journal of Arboriculture, 11(11): 330-339. 
CRAUL, P.J. 1999. Urban soils: Applications and practices. John Wiley, New York, 66 p.

CURCIO, G.R.; LIMA, V.C.; GIAROLA, N.F.B. 2004. Antropossolos: Proposta de Ordem $\left(1^{a}\right.$ aproximação). Embrapa Florestas, Colombo/ PR, 49 p. (Documentos, 101).

DAGNINO, R.S. 2007. Riscos ambientais na Bacia Hidrográfica do Ribeirão das Pedras. Instituto de Geociências, Universidade Estadual de Campinas, Campinas, Dissertação de Mestrado, 127 p.

FANNING, D.S.; FANNING, C.B.F. 1989. Soil: morphology, genesis and classification. John Wiley \& Sons, New York, 416 p.

FERNANDES, A.J.; AZEVEDO SOBRINHO, J.M.; TEIXEIRA, A.L. 1993. Mapa Geológico do Município de Campinas (Anexo 2.1) e Mapa de Pontos Geológicos e Geomorfológicos do Município de Campinas (Anexo 2.2). In: Instituto Geológico (SP) Subsídios do meio físico geológico ao planejamento do Município de Campinas. São Paulo, 3 vols. (Relatório Técnico do Instituto Geológico).

FGV/EASP - FUNDAÇÃO GETÚLIO VARGAS/ESCOLA DE ADMINISTRAÇÃO DE EMPRESAS DE SÃO PAULO. 2004. Parque Dom Pedro Shopping - Sistema de Gestão Ambiental. In: $2^{\circ}$ Prêmio FGV-EASP de Responsabilidade Social no Varejo. Finalista na categoria shopping Center.

GOMES, E.P.C. 2006. Florística e fitossociologia como ferramentas do processo de RAD. In: L.M. Barbosa (coord.) Manual para recuperação de áreas degradadas do Estado de São Paulo - Matas ciliares do interior paulista. São Paulo, Instituto de Botânica, p. 70-74.

IAC - INSTITUTO AGRONÔMICO DE CAMPINAS. 1997. Recomendações de adubação e calagem para o Estado de São Paulo. Campinas/SP: Instituto Agronômico/Fundação IAC, $2^{\mathrm{a}}$ ed. rev. atual. 285 p. (Boletim Técnico, 100).

IBGE - INSTITUTO BRASILEIRO DE GEOGRAFIA E ESTATÍSTICA. 2007. Manual Técnico de Pedologia. Rio de Janeiro: IBGE, $2^{\mathrm{a}}$ ed., 316 p. (Manuais técnicos em geociências, 4).

IBGE - INSTITUTO BRASILEIRO DE GEOGRAFIA E ESTATÍSTICA. 2010. Censo Demográfico 2010.

IBGE - INSTITUTO BRASILEIRO DE GEOGRAFIA E ESTATÍSTICA. 2012. Manual Técnico da Vegetação Brasileira. Rio de Janeiro: IBGE, $2^{\mathrm{a}}$ ed. revista e ampliada, $92 \mathrm{p}$. (Manuais técnicos em geociências, 1).

IUSS - INTERNATIONAL UNION OF SOIL SCIENCES. 2014. World Reference Base for Soil Resources 2014. International soil classification system for naming soils and creating legends for soil maps. FAO, Rome (World Soil Resources Reports, 106).

JENKINS, R. 1999. X-ray Fluorescence spectrometry. John Wiley, New York, $2^{\text {nd }}$ ed., 207 p.

JIM, C.Y. 1998. Urban soil characteristcs and limitations for landscape planting in Hong Kong. Landscape and Urban Planning, 40(4): 235-249. https://doi.org/10.1016/ S0169-2046(97)00117-5

OLIVEIRA, A.M.S. 1994. Depósitos tecnogênicos $e$ assoreamento de reservatórios: Exemplo do Reservatório de Capivara, Rio Paranapanema, SP/PR. Departamento de Geografia, Faculdade de Filosofia, Letras e Ciências Humanas, Universidade de São Paulo, São Paulo, Tese de Doutorado, 211 p.

OLIVEIRA, A.M.S. 2005. Estudos sobre o Tecnógeno do Brasil. In: ABEQUA, Simpósio Brasileiro do Tecnógeno, 1, Guarapari, CD-ROM. Disponível em http://www.abequa. org.br/trabalhos/0304_antonio_manoel_de_ oliveira.pdf. Acessado em 04 jun. 2017.

PEDRON, F.A.; DALMOLIN, R.S.D.; AZEVEDO, A.C.; KAMINSKI, J. 2004. Solos Urbanos. Ciência Rural, 34(5): 1647-1653. http://dx. doi.org/10.1590/S0103-84782004000500053

PELOGGIA, A.U.G. 2015. Camadas que falam sobre o ser humano, caso encontrem arqueólogos e geólogos que as escutem: rumo a uma arqueogeologia interpretativa dos depósitos tecnogênicos. In: A.M. Ortega \& e A.U.G. Peloggia (orgs.) Entre o Arcaico 
e o Contemporâneo: ensaios fluindo entre Arqueologia, Psicanálise, Antropologia e Geologia. São Paulo, Iglu, p.189-221.

PELOGGIA, A.U.G. 2017. O que produzimos sob nossos pés? Uma revisão comparativa dos conceitos fundamentais referentes a solo e terrenos antropogênicos. Revista UNG - Geociências, 16(1): 102-127.

PELOGGIA, A.U.G.; OLIVEIRA A.M.S.; OLIVEIRA A.A.; SILVA E.C.N.; NUNES J.O.R. 2014. Technogenic geodiversity: a proposal on the classification of artificial ground. Quaternary and Environmental Geosciences, 5(1): 28-40. http://dx.doi. org/10.5380/abequa.v5i1.34823

PREFEITURA DE CAMPINAS. 2017. Conheça Campinas - Origens. Disponível em www. campinas.sp.gov.br. Acessado em 20 dez. 2016 e 05 jul. 2017.

REMIÃO, F. 2012/2013. Bário: comunicação de risco. Trabalho realizado no âmbito da Disciplina Toxicologia Mecanística do Curso de Mestrado Integrado em Ciências Farmacêuticas. Faculdade de Farmácia da Universidade do Porto, Porto/Portugal. Disponível em http://bario2.wixsite.com/bario/toxicidade. Acessado em 18 jul. 2017.

SANTOS, R.D.; SANTOS, H.G.; KER, J.C.; ANJOS, L.H.C.; SHIMIZU, S.H. 2013. Manual de Descrição e Coleta de Solo no Campo. Sociedade Brasileira da Ciência do Solo, Viçosa, $6^{\mathrm{a}}$ ed. (Revisada e Ampliada), $102 \mathrm{p}$.

SCHAD, P. 2018. Technosols in the World Reference Base for Soil Resources - history and definitions, Soil Science and Plant Nutrition, 64(2): 138-144, http://dx.doi.org/10.1080/003 80768.2018 .1432973

SMA/SP-IBAMA - SECRETARIA DE ESTADO DE MEIO AMBIENTE DE SÃO PAULO INSTITUTO BRASILEIRO DO MEIO AMBIENTE E DOS RECURSOS NATURAIS RENOVÁVEIS. 1994. Resolução conjunta SMA IBAMA/SP $\mathrm{n}^{\circ} 1$, de 17 de fevereiro de 1994. Considerando o disposto no art. 23, Incisos VI e VII da Constituição Federal e a necessidade de se definir vegetação primária $\mathrm{e}$ secundária nos estágios pioneiro, inicial, mé- dio e avançado de regeneração de Mata Atlântica em cumprimento ao disposto no art. $6^{\circ}$ do Decreto $n^{\circ} 750$, de 10 de Fevereiro de 1993, na Resolução CONAMA 10 de 10 de Outubro de 1993 e a fim de orientar os procedimentos de licenciamento de exploração da vegetação nativa no Estado de São Paulo. São Paulo, SMA/ SP-IBAMA.

SINGH, B.R.; STEINNES, E. 1994. Soil and water contamination by heavy metals. In: R. Lai \& B.A. Stewart (Eds.) Advances in soil science: soil process and water quality. Lewis, USA, p. 233-237.

STROGANOVA, M.N.; AGARKOVA, M.G. 1993. Urban soils: experimental study and classification (exemplified by the soils of southwestern Moscow). Eurasian Soil Science, 25(3): 59-69.

TEIXEIRA, R.C. 2015. Antropossolos em Guarapari (ES): a geografia dos solos antrópicos. Departamento de Geografia, Centro de Ciências Humanas, Letra e Artes, Universidade Federal de Viçosa, Monografia, 46 p.

UNITED NATIONS. 2015. World Urbanization Prosprects: the 2014 revision. Department of Economic and Social Affairs, Population Division, 493 p. (ST/ESA/SER.A/366).

USDA - UNITED STATES DEPARTMENT OF AGRICULTURE. 1951. Soil Survey Manual. USDA, Washington/DC, 503 p. (Handbook, 18).

VENDEMIATTO, M.A.; ENZWEILER, J. 2001. Routine control of accuracy in silicate rock analysis by X-ray fluorescence spectrometry. Geostandards and Geoanalytical Research, 25: 283-291.

VITORINO, J.C.; ANDRADE, M.R.M.; PELOGGIA, A.U.G.; SAAD, A.R.; OLIVEIRA, A.M.S. 2016. Terrenos tecnogênicos do Jardim Fortaleza, bacia hidrográfica do córrego do Entulho, Guarulhos (SP): mapeamento geológico, estratigrafia, geomorfologia e arqueologia da paisagem. Revista $U N G$ - Geociências, 15(2): 33-60.. 
Endereço dos autores:

Sara Marques Putrino - Xingu Geotecnia e Meio Ambiente, Rua Alberto Jackson Byington, 201, CEP: 13070-063, Jardim Chapadão, Campinas, SP, Brasil.E-mail: saraputrino@gmail.com

Francisco Sergio Bernardes Ladeira - Instituto de Geociências, Universidade Estadual de Campinas, Rua Carlos Gomes, 250, CEP: 13083-855, Campinas, SP, Brasil.E-mail: ladeira@unicamp.br

Artigo submetido em 30 de novembro de 2018, aceito em 20 de fevereiro de 2019. 